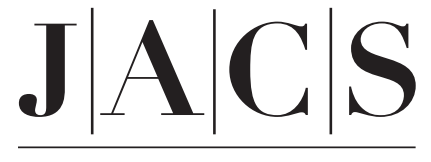

A R T I C L E S

Published on Web 12/12/2007

\title{
Ruthenium Complexes with Vinyl, Styryl, and Vinylpyrenyl Ligands: A Case of Non-innocence in Organometallic Chemistry
}

\author{
Jörg Maurer, ${ }^{\dagger, \neq}$ Michael Linseis, ${ }^{\dagger}$ Biprajit Sarkar, ${ }^{\ddagger}$ Brigitte Schwederski, ${ }^{\ddagger}$ \\ Mark Niemeyer, ${ }^{\ddagger}$ Wolfgang Kaim, ${ }^{\ddagger}$ Stanislav Záliš,,${ }^{\star}$ Chris Anson, ${ }^{\perp}$ \\ Manfred Zabel, ${ }^{\dagger}$ and Rainer F. Winter ${ }^{*}, \dagger$ \\ Contribution from the Institut für Anorganische Chemie der Universität Regensburg, \\ D-93040 Regensburg, Germany, Institut für Anorganische Chemie der Universität Stuttgart, \\ D-70563 Stuttgart, Germany, J. Heyrovský Institute of Physical Chemistry v.v.i., Academy of \\ Sciences of the Czech Republic, Czech Republic, Institut für Anorganische Chemie der \\ Universität Karlsruhe, D-76131 Karlsruhe, Germany
}

Received August 8, 2007; E-mail: rainer.winter@chemie.uni-regensburg.de; stanislav.zalis@jh-inst.cas.cz

\begin{abstract}
We herein describe a systematic account of mononuclear ruthenium vinyl complexes $L-\{R u\}-$ $\mathrm{CH}=\mathrm{CH}-\mathrm{R}$ where the phosphine ligands at the $\left(\mathrm{PR}_{3}^{\prime}\right)_{2} \mathrm{Ru}(\mathrm{CO}) \mathrm{Cl}=\{\mathrm{Ru}\}$ moiety, the coordination number at the metal $\left(\mathrm{L}=4\right.$-ethylisonicotinate or a vacant coordination site) and the substituent $\mathrm{R}\left(\mathrm{R}={ }^{\mathrm{b}} \mathrm{butyl}\right.$, phenyl, 1-pyrenyl) have been varied. Structures of the enynyl complex $\mathrm{Ru}(\mathrm{CO}) \mathrm{Cl}\left(\mathrm{PPh}_{3}\right)_{2}\left(\eta^{1}: \eta^{2}{ }^{n} \mathrm{BuHC}=\right.$ $\mathrm{CHC} \equiv \mathrm{C}^{n} \mathrm{Bu}$ ), which results from the coupling of the hexenyl ligand of complex 1a with another molecule of 1-hexyne, of the hexenyl complexes ( $\left.{ }^{n} \mathrm{BuCH}=\mathrm{CH}\right) \mathrm{Ru}(\mathrm{CO}) \mathrm{Cl}\left(\mathrm{P}^{\mathrm{P}} \mathrm{Pr}_{3}\right)_{2}(\mathbf{1 c})$ and $\left({ }^{n} \mathrm{BuCH}=\mathrm{CH}\right) \mathrm{Ru}(\mathrm{CO}) \mathrm{Cl}$ $\left(\mathrm{PPh}_{3}\right)_{2}\left(\mathrm{NC}_{5} \mathrm{H}_{4} \mathrm{COOEt}-4\right)(\mathbf{1 b})$, and of the pyrenyl complexes (1-Pyr-CH=CH) Ru(CO)Cl(PiPr$)_{2}(\mathbf{3 c})$ and $(1-\mathrm{Pyr}-\mathrm{CH}=\mathrm{CH}) \mathrm{Ru}(\mathrm{CO}) \mathrm{Cl}\left(\mathrm{PPh}_{3}\right)_{3}(3 \mathrm{a}-\mathrm{P})$ have been established by $\mathrm{X}$-ray crystallography. All vinyl complexes undergo a one-electron oxidation at fairly low potentials and a second oxidation at more positive potentials. Anodic half-wave or peak potentials show a progressive shift to lower values as $\pi$-conjugation within the vinyl ligand increases. Carbonyl band shifts of the metal-bonded $\mathrm{CO}$ ligand upon monooxidation are significantly smaller than is expected of a metal-centered oxidation process and are further diminished as the vinyl $\mathrm{CH}=\mathrm{CH}$ entity is incorporated into a more extended $\pi$-system. ESR spectra of the electrogenerated radical cations display negligible $g$-value anisotropies and small deviations of the average $g$-value from that of the free electron. The vinyl ligands thus strongly contribute to or even dominate the anodic oxidation processes. This renders them a class of truly "non-innocent" ligands in organometallic ruthenium chemistry. Experimental findings are fully supported by quantum chemical calculations: The contribution of the vinyl ligand to the HOMO increases from $46 \%$ (Ru-vinyl delocalized) to $84 \%$ (vinyl dominated) as R changes from nbutyl to 1-pyrenyl.
\end{abstract}

\section{Introduction}

Redox active ligands that actively participate in electrontransfer processes, in conjunction with appropriate redox active transition metal entities, render an assignment of redox states ambiguous. ${ }^{1}$ Such behavior has been denoted as "non-innocent". ${ }^{2}$ When the energy barrier for intramolecular electron transfer is low, charge and unpaired spin are delocalized over the metal ion and the "non-innocent" ligand(s). This may either result in metal stabilized radicals ${ }^{3-5}$ or in the stabilization of

\footnotetext{
†niversität Regensburg.

$\doteqdot$ Universität Stuttgart.

$\S$ J. Heyrovský Institute.

$\perp$ Universität Karlsruhe.

(1) Ward, M. D.; McCleverty, J. A. Dalton Trans. 2002, 275-288.

(2) Jørgensen, C. K. Coord. Chem. Rev. 1966, 1, 164-178.

(3) Büttner, T.; Geier, J.; Frison, G.; Harmer, J.; Calle, C.; Schweiger, A.; Schönberg, H.; Grützmacher, H. Science 2005, 307, 235-238.

(4) de Bruin, B.; Hetterscheid, D. G. H. Eur. J. Inorg. Chem. 2007, 211-230.

(5) Fernández, F. J.; Venkatesan, K.; Blacque, O.; Alfonso, M.; Schmalle, H. W.; Berke, H. Chem. Eur. J. 2003, 9, 6192-6206.
}

unusual (formal) oxidation states at the metal as, for example, in compound I of cytochrome P-450. ${ }^{6}$ If, on the other hand, the energy barrier of intramolecular electron transfer is sufficiently high, "non-innocent" behavior gives rise to the phenomenon of valence tautomerism. ${ }^{7-10}$ The charge distribution within valence tautomers can be controlled by exterior physical stimuli such as pressure, light, or applied magnetic field. ${ }^{11,12}$ Such behavior sets the ground for the development of molecule based,

(6) Makris, T. M.; Von Koenig, K.; Schlichting, I.; Sligar, S. G. J. Inorg Biochem. 2006, 100, 507-518.

(7) Lever, A. B. P.; Masui, H.; Metcalfe, R. A.; Stufkens, D. J.; Dodsworth, E. S.; Auburn, P. R. Coord. Chem. Rev. 1993, 125, 317-331.

(8) Pierpont, C. G.; Lange, C. W. The Chemistry of Transition Metal Complexes Containing Catechol and Semiquinone Ligands. In Progress in Inorganic Chemistry; Karlin, K. D., Ed.; Wiley: Hoboken, NJ, 1994; Vol. 41, pp $331-442$.

(9) Pierpont, C. G. Coord. Chem. Rev. 2001, 216-217, 99-125.

(10) Evangelio, E.; Ruiz-Molina, D. Eur. J. Inorg. Chem. 2005, 2957-2971.

(11) Sato, O.; Tao, J.; Zhang, Y.-Z. Angew. Chem., Int. Ed. 2007, 46, 21522187.

(12) Sato, O.; Cui, A.; Matsuda, R.; Tao, J.; Hayami, S. Acc. Chem. Res. 2007, $40,361-369$

10.1021/ja075547t CCC: $\$ 40.75$ @ 2008 American Chemical Society

J. AM. CHEM. SOC. $2008,130,259-268$ - 259 
switchable materials with possible applications, inter alia, for data storage.

Set against this background there is a continued need to prepare and identify redox-active, potentially non-innocent ligands and to study their interaction with various transitionmetal moieties. Important sets of redox-active ligands are based on tetracyanoethene (TCNE), 7,7,8,8-tetracyano- $p$-quinodimethane (TCNQ), ${ }^{13}$ or dithiolenes, ${ }^{14,15}$ dioxolenes,,${ }^{9,16}$ diimines,,${ }^{15}$ and ligands with mixed donor atoms. While most of the work in this area has concentrated on inorganic coordination compounds, ligands like TCNE and TCNQ may equally well coordinate organometallic entities. ${ }^{17-22}$ Potentially redox-active ligands that form metal-carbon bonds for use in organometallic chemistry are, however, much less well precedented. Examples are paramagnetic alkene complexes of rhodium and iridium, ${ }^{4}$ and manganese complexes containing $\pi$-coordinated quinones (or semiquinonates or catecholates, respectively). ${ }^{23-25}$ While individual building blocks are organometallic in nature, the quinone complexes still rely on the traditional metal-dioxolene chelate linkage for their interesting electronic properties. The radical derived from a triphenylmethyl substituted vinylferrocene constitutes a rare example of a genuine organometallic valence tautomeric system with a temperature-dependent equilibrium between $\mathrm{Fc}-\mathrm{CH}=\mathrm{CH}-\mathrm{CPh}_{3}{ }^{\circ}$ andFc ${ }^{+}-\mathrm{CH}=\mathrm{CH}-\mathrm{CPh}_{3}{ }^{-}$-states. ${ }^{26}$

We have recently investigated the anodic electrochemistry of divinylphenylene-bridged diruthenium complexes $\left\{\left(\mathrm{PR}_{3}\right)_{2}\right.$ $\left.(\mathrm{CO}) \mathrm{Cl}\left(\mathrm{L}^{\prime}\right) \mathrm{Ru}\right\}_{2}\left\{\mu-\mathrm{C}_{6} \mathrm{H}_{4}(\mathrm{CH}=\mathrm{CH})_{2}-1,3\right.$ or $\left.-1,4\right)\left(\mathrm{R}=\mathrm{Ph}, \mathrm{L}^{\prime}\right.$ $=4$-substituted pyridine; $\mathrm{R}={ }^{i} \mathrm{Pr}, \mathrm{L}^{\prime}=$ none $)^{27,28}$ and studied their radical cations and dications by $\mathrm{UV}-\mathrm{vis}-\mathrm{NIR}$, IR, and ESR spectroscopy. These studies indicated bridge-dominated oxidation processes although the oxidation potentials of ruthenium complexes are intrinsically lower than those of comparable donor substituted phenylene vinylenes. The metal versus vinyl ligand contribution to the frontier molecular orbitals (FMOs) depends on the energy gap between the appropriate metal $\mathrm{d}$ levels and the $\pi$ orbitals of the vinyl ligand. Raising the energy of the ruthenium $d$ manifold or decreasing the energy of the ligand $\pi$ orbitals enhances the metal character of the FMOs.

(13) Miller, J. S. Inorg. Chem. 2000, 39, 4392-4408.

(14) Kirk, M. L.; McNaughton, R. L.; Helton, M. E. Electronic and Spectroscopic Properties of Metal Dithiolene Complexes. In Progress in Inorganic Chemistry; Karlin, K. D., Ed.; Wiley: Hoboken, NJ, 2004; Vol. 52, pp $111-212$.

(15) Ray, K.; Petrenko, T.; Wieghardt, K.; Neese, F. Dalton Trans. 2007, 15521566.

(16) Rall, J.; Wanner, M.; Albrecht, M.; Hornung, F. M.; Kaim, W. Chem. Eur. J. 1999, 5, 2802-2809.

(17) Sacher, W.; Nagel, B.; Beck, W. Chem. Ber. 1987, 120, 895.

(18) Gross-Lannert, R.; Kaim, W.; Olbrich-Deussner, B. Inorg. Chem. 1990, 29, 5046-5053

(19) Hartmann, H.; Kaim, W.; Hartenbach, I.; Schleid, T.; Wanner, M.; Fiedler, J. Angew. Chem., Int. Ed. 2001, 40, 2842-2844.

(20) Moscherosch, M.; Waldöhr, E.; Binder, H.; Kaim, W.; Fiedler, J. Inorg. Chem. 1995, 34, 4326-4335.

(21) Baumann, F.; Kaim, W.; Olabe, J. A.; Parisse, A.; Jordanov, J. J. Chem. Soc., Dalton Trans. 1997, 4455-4460.

(22) Leirer, M.; Knör, G.; Vogler, A. Inorg. Chem. Commun. 1999, 2, 110112

(23) Oh, M.; Carpenter, G. B.; Sweigart, D. A. Organometallics 2003, 22, 14371442.

(24) Oh, M.; Carpenter, G. B.; Sweigart, D. A. Macromol. Symp. 2003, 196, $101-112$.

(25) Oh, M.; Carpenter, G. B.; Sweigart, D. A. Acc. Chem. Res. 2004, 37, 1-11.

(26) Ratera, I.; Ruiz-Molina, D.; Renz, F.; Ensling, J.; Wurst, K.; Rovira, C.; Gütlich, P.; Veciana, J. J. Am. Chem. Soc. 2003, 125, 1462-1463.

(27) Maurer, J.; Winter, R. F.; Sarkar, B.; Fiedler, J.; Záliš, S. Chem. Commun. 2004, 1900-1901.

(28) Maurer, J.; Sarkar, B.; Schwederski, B.; Kaim, W.; Winter, R. F.; Záliš, S. Organometallics 2006, 25, 3701-3712.
Chart 1. The Complexes Employed in This Study
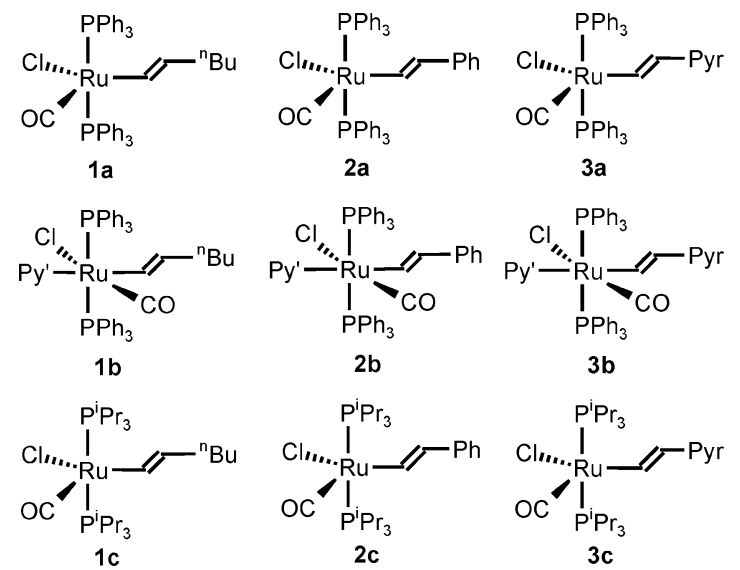

$P y^{\prime}=$

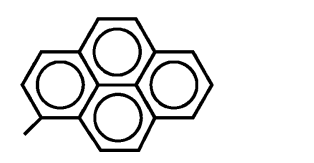

Thus, butadienediyl-bridged diruthenium complexes constitute completely delocalized organometallic $\pi$-chromophores that defy any assignment of the redox processes as metal or ligand based. ${ }^{29}$ To further develop this chemistry toward true organometallic valence tautomers and to extended chainlike arrays with high electron mobility along the main chain, it is mandatory to understand and to quantify the principal factors that govern the electron distribution within the ruthenium vinyl entities. Dinuclear systems present the added complexity of possible metal-metal interactions across the bridging ligands. We therefore turned to the mononuclear complexes shown in Chart 1. These were designed such as to allow us to study how (i) extending the $\pi$-system of the vinyl ligand, (ii) manipulating the electron density at the metal atom, and (iii) varying the degree of coordinative saturation at the metal atom affect the bonding, the anodic behavior, and metal versus ligand contribution to the redox-orbitals.

\section{Results and Discussion}

Syntheses and Characterization of the Vinyl Complexes. Ruthenium vinyl complexes $(\mathrm{RCH}=\mathrm{CH}) \mathrm{Ru}(\mathrm{CO}) \mathrm{Cl}\left(\mathrm{PR}_{3}\right)_{2}$ are easily prepared from hydride complexes $\mathrm{HRu}(\mathrm{CO}) \mathrm{Cl}\left(\mathrm{PR}_{3}\right)_{n}\left(\mathrm{PR}_{3}\right.$ $\left.=\mathrm{PPh}_{3}, n=3 ; \mathrm{PR}_{3}=\mathrm{P}^{i} \mathrm{Pr}_{3}, \mathrm{PCy}_{3}, n=2\right)$ via hydroruthenation of terminal alkynes. Metal hydride insertion into the $\mathrm{C} \equiv \mathrm{C}$ bond occurs in a regio- and stereospecific manner and results in the anti-Markovnikov product where the metal atom is connected to the terminal carbon atom and the remaining substituent is in a trans position at the vinyl group. Depending on the reaction conditions $\mathrm{HRu}(\mathrm{CO}) \mathrm{Cl}\left(\mathrm{PPh}_{3}\right)_{3}$ either gives coordinatively saturated six-coordinated tris(phosphine) derivatives or coordinatively unsaturated five-coordinated square pyramidal bis(phosphine) complexes with a vacant coordination site trans to the apical vinyl ligand. ${ }^{30-32}$ Irrespective of five- or six-

(29) Maurer, J.; Sarkar, B.; Zalis, S.; Winter, R. F. J. Solid State Electrochem. 2005, 9, 738-749.

(30) Torres, M. R.; Vegas, A.; Santos, A. J. Organomet. Chem. 1986, 309, 169177.

(31) Hill, A. F. Comprehensive Organometallic Chemistry II; Shriver, D. E., Bruce, M. I., Eds.; Pergamon: Oxford, England, 1995; Vol. 7, pp 399411.

(32) Seetharaman, S. K.; Chung, M.-C.; Englich, U.; Ruhlandt-Senge, K.; Sponsler, M. B. Inorg. Chem. 2007, 46, 561-567. 
coordination, $\mathrm{PPh}_{3}$ substituted vinyl complexes readily react with sterically less demanding two electron ligands such as $\mathrm{CO}$, isonitriles, amines, or pyridines to give octahedral 18 valence electron complexes with the newly introduced donor opposite to the vinyl ligand. The 16 valence electron complexes $(\mathrm{RCH}=$ $\mathrm{CH}) \mathrm{Ru}(\mathrm{CO}) \mathrm{Cl}\left(\mathrm{P}^{i} \mathrm{Pr}_{3}\right)_{2}$, on the other hand, are less prone to addition of a pyridine ligand but may still add $\mathrm{CO}$, isonitriles, or, under simultaneous chloride substitution, a bidentate monoanionic ligand such as acetate. ${ }^{33,34}$

The reaction of $\mathrm{HRu}(\mathrm{CO}) \mathrm{Cl}\left(\mathrm{PPh}_{3}\right)_{3}$ with 1-hexyne gave an equilibrium mixture of the five- and six-coordinated bis- and tris(phosphine) hexenyl complexes. Variable temperature NMR spectroscopy in $\mathrm{CD}_{2} \mathrm{Cl}_{2}$ indicates that the equilibrium lies completely on the side of the red 16 valence electron complex and free phosphine at room temperature, while only sixcoordinated $\left({ }^{n} \mathrm{BuCH}=\mathrm{CH}\right)\left(\mathrm{PPh}_{3}\right)_{3}(\mathrm{CO}) \mathrm{ClRu}$ is present at or below $203 \mathrm{~K}$ or in the solid. Similar findings were just reported for the styryl complex $\mathbf{2 a} .{ }^{32}$

When this equilibrium mixture was reacted with isonicotinate, a mixture of the desired complex $\mathbf{1 b}$, unreacted 1a, and the disubstitution product $\left[\left(\mathrm{PPh}_{3}\right)_{2}(\mathrm{CO})\left(\mathrm{NC}_{5} \mathrm{H}_{4} \mathrm{COOEt}\right)_{2}\left({ }^{n} \mathrm{BuCH}=\right.\right.$ $\mathrm{CH}) \mathrm{Ru}]^{+} \mathrm{Cl}^{-}$was formed from which no pure compound could be isolated. Complex $\mathbf{1 b}$ was finally prepared from $\mathrm{HRu}(\mathrm{CO})$ $\mathrm{Cl}\left(\mathrm{PPh}_{3}\right)_{2}\left(\mathrm{NC}_{5} \mathrm{H}_{4} \mathrm{COOEt}\right)$. Like in the case of $\mathrm{HRu}\left(\mathrm{P}^{i} \mathrm{Pr}_{2} \mathrm{Ph}\right)_{2-}$ (CO)Cl(py) ${ }^{35}$ this latter hydride was obtained as a 78:22 mixture of two mutually interconverting isomers that differ with respect to the arrangement of the four different ligands in the equatorial plane. According to ${ }^{1} \mathrm{H}$ ROESY the major isomer has the isonicotinate cis to the hydride. For the major isomer slow rotation of the substituted pyridine at room temperature is evident from the four different pyridine resonance signals. Cooling to $193 \mathrm{~K}$ is required for the minor isomer where the isonicotinate ligand is trans to the hydride in order to freeze pyridine rotation $\left(T_{\mathrm{c}} \approx 208 \mathrm{~K}\right)$. This large difference in rotational barriers may arise from hydrogen bonding between the ortho proton of the pyridine and the hydride ligand. The inequivalence of the 2,6- and 3,5-hydrogen atoms in both isomers points to static structures where the pyridine planes avoid eclipsing the PRuP axis. Similar observations have been made for pyridine adducts of $\mathrm{HRu}(\mathrm{CO}) \mathrm{X}\left(\mathrm{P}^{t} \mathrm{Bu}_{2} \mathrm{Me}\right)_{2}(\mathrm{X}=$ monoanionic ligand $)$ where the pyridine ligand is in a trans position to the hydride. ${ }^{36,37}$ Treating this isomeric mixture with 1-hexyne results in the exclusive formation of $\mathbf{1 b}$. Under gentle warming $\mathrm{HRu}(\mathrm{CO})$ $\mathrm{Cl}\left(\mathrm{PPh}_{3}\right)_{3}$ reacted with excess 1-hexyne to give the dodec-5en-7-ynyl complex $\mathrm{Ru}(\mathrm{CO}) \mathrm{Cl}\left(\mathrm{PPh}_{3}\right)_{2}\left(\eta^{1}: \eta^{2}{ }^{n} \mathrm{BuHC}=\mathrm{CH}-\mathrm{C} \equiv\right.$ $\mathrm{C}^{n} \mathrm{Bu}$ ), which was studied by $\mathrm{X}$-ray crystallography (vide infra). Closely related butenynyl complexes have already been reported. ${ }^{38}$

All complexes of this study (Chart 1) were investigated and characterized by the usual spectroscopic and analytical methods including multinuclear NMR, IR, and electronic spectroscopy. Characteristic features in their ${ }^{1} \mathrm{H}$ NMR spectra are the two

(33) Werner, H.; Esteruelas, M. A.; Otto, H. Organometallics 1986, 5, 2295.

(34) Werner, H.; Meyer, U.; Peters, K.; von Schnering, H. G. Chem. Ber. 1989 $122,2089-2107$.

(35) Werner, H.; Stüer, W.; Weberndörfer, B.; Wolf, J. Eur. J. Inorg. Chem. 1999, 1707-1713.

(36) Poulton, J. T.; Folting, K.; Streib, W. E.; Caulton, K. G. Inorg. Chem. 1992, 31, 3190-3191.

(37) Poulton, J. T.; Sigalas, M. P.; Folting, K.; Streib, W. E.; Eisenstein, O.; Caulton, K. G. Inorg. Chem. 1994, 33, 14676-1485.

(38) Santos, A.; López, J.; Matas, L.; Galán, A.; Echavarren, A. M. Organometallics 1993, 12, 4215-4218.

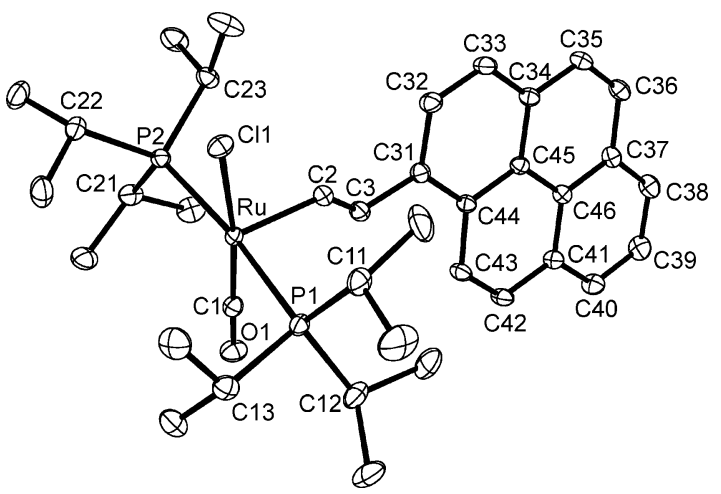

Figure 1. ORTEP representation of complex $\mathbf{3 c} \cdot \mathbf{C H C l}_{\mathbf{3}}$ at a $50 \%$ probability level.

doublets for the vinyl protons. The signal of the vinyl proton at the metal-bonded carbon atom $\mathrm{C}_{\alpha}$ resonates at lower field with $\delta$ values ranging from 9.26 to $6.90 \mathrm{ppm}$. It is less sensitive to the ligand environment than the one at the neighboring carbon atom $\mathrm{C}_{\beta}$ where the shift ranges from 8.79 to $4.76 \mathrm{ppm}$. The vinyl carbon atoms resonate at $156.4-138.4 \mathrm{ppm}\left(\mathrm{C}_{\alpha}\right)$ and 139.6-130.7 ppm $\left(\mathrm{C}_{\beta}\right)$, respectively. Addition of the substituted pyridine ligand to complexes $\mathbf{1 a}, \mathbf{2 a}$, and $\mathbf{3 a}$ shifts the resonance signals of the vinylic protons and those of the $\mathrm{RuCH}=\mathrm{CH}$ and the $\mathrm{RuCH}=\mathrm{CH}$ carbon atom to lower field and that of the ${ }^{31} \mathrm{P}$ resonance to higher field. In their IR spectra the vinyl complexes show an intense band of the $\mathrm{CO}$ stretch. The position of this band is more sensitive to the number and nature of the phosphine ligands than to that of the vinyl substituent. Thus, in every series $1 \mathbf{a}-\mathbf{c}, \mathbf{2} \mathbf{a}-\mathbf{c}$, and $\mathbf{3 a}-\mathbf{c}$ the $\mathrm{CO}$ band shifts follow the sequence 1a, 2a, 3a $>1 \mathbf{b}, \mathbf{2 b}, \mathbf{3 b}>\mathbf{1 c}, \mathbf{2 c}, \mathbf{3 c}$ such that the five-coordinated $\mathrm{P}^{i} \mathrm{Pr}_{3}$ substituted complexes feature the most electron-rich metal centers.

$\mathrm{X}$-ray Structures of $1 \mathrm{~b}, 1 \mathrm{c}, 3 \mathrm{c} \cdot \mathrm{CHCl}_{3}, 3 \mathrm{a}-\mathrm{P} \cdot 2 \mathrm{CH}_{2} \mathrm{Cl}_{2}$, and of $\mathrm{Ru}(\mathrm{CO}) \mathrm{Cl}\left(\mathrm{PPh}_{3}\right)_{\mathbf{2}}\left(\eta^{\mathbf{1}}: \eta^{2}{ }_{-}{ }^{n} \mathrm{BuHC}=\mathrm{CHC} \equiv \mathrm{C}^{n} \mathrm{Bu}\right)$. Crystals of the five-coordinated vinyl complex 1c were grown from methanol, while $\mathbf{3 c}$ crystallizes from chloroform as a monosolvate. Figure 1 provides a plot of the complex molecule of $\mathbf{3 c}$. $\mathbf{C H C l}_{\mathbf{3}}$ along with the atomic numbering scheme. A similar plot of 1c is given as Figure S2 of the Supporting Information. In each of the two structures the ruthenium atom adopts the distorted square pyramidal coordination with the strongly trans influencing vinyl ligand in the apical position that is familiar of $\mathrm{M}(\mathrm{CO}) \mathrm{Cl}\left(\mathrm{PR}_{3}\right)_{2} \mathrm{X}(\mathrm{X}=\mathrm{H}$, vinyl, alkyl, aryl $)$ complexes. ${ }^{33,39-42}$ Distortions arise from a compression of the $\mathrm{P}-\mathrm{Ru}-\mathrm{P}$ angle toward the vacant coordination site to $168.63(4)^{\circ}(1 \mathrm{c})$ or $173.72-$ $(1)^{\circ}(\mathbf{3 c})$ and a slight displacement of the metal atom by $0.152-$ (1) $\AA$ (3c) or 0.198 (1) $\AA$ (1c) out of the best plane defined by the four donor atoms at the pyramid base. The vinyl ligand resides in the plane defined by the $\mathrm{Ru}, \mathrm{Cl}$, and $\mathrm{C}(1)$ atoms as it is shown by the torsional angles $\mathrm{Cl}(1)-\mathrm{Ru}-\mathrm{C}(2)-\mathrm{C}(3)$ of $-177.5(5)$ or $177.7(1)^{\circ}$ for $1 c$ or $3 \mathbf{c}$, respectively. The angles $\mathrm{Ru}-\mathrm{C} 2-\mathrm{C} 3-\mathrm{C} 4$ of $176.2(5)(\mathbf{c})$ and $\mathrm{Ru}-\mathrm{C} 2-\mathrm{C} 3-\mathrm{C} 31$ of $178.6(1)^{\circ}(3 \mathbf{c})$ signal hardly any twisting of the vinyl double bond.

(39) Huang, D.; Streib, W. E.; Bollinger, J. C.; Caulton, K. G.; Winter, R. F.; Scheiring, T. J. Am. Chem. Soc. 1999, 121, 8087-8097.

(40) Jung, S.; Ilg, K.; Brandt, C. D.; Wolf, J.; Werner, H. Eur. J. Inorg. Chem 2004, 469-480.

(41) Alcock, N. W.; Cartwright, J.; Hill, A. F.; Marcellin, M.; Rawles, H. M. J. Chem. Soc., Chem. Commun. 1995, 369-370.

(42) Maruyama, Y.; Yamamura, K.; Sagawa, T.; Katayama, H.; Ozawa, F. Organometallics 2000, 19, 1308-1318. 


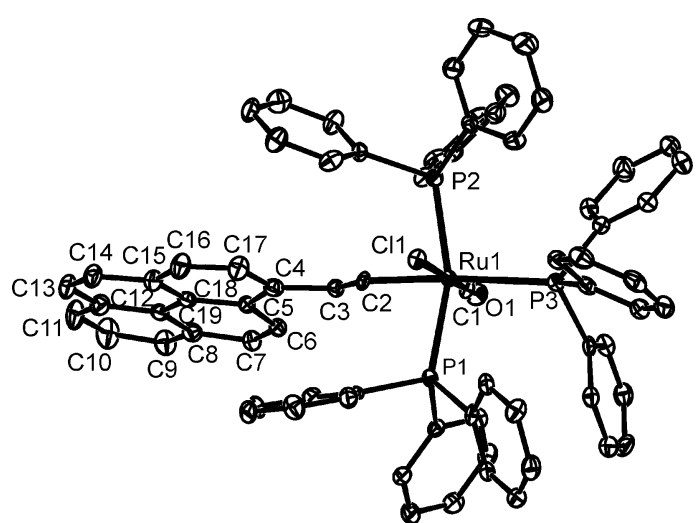

Figure 2. ORTEP representation of one of the two independent molecules of $3 \mathbf{a}-\mathbf{P}$ at a $50 \%$ probability level.

The pyrenyl part of $\mathbf{3 c}$, while strictly planar, is rotated out of the $\mathrm{Ru}-\mathrm{C} 2-\mathrm{C} 3$ plane by about $25^{\circ}$ such that the vinylpyrenyl plane intersects the $\mathrm{P}-\mathrm{Ru}-\mathrm{P}$ axis at an angle of about $67^{\circ}$. The $\mathrm{Ru}-\mathrm{C} 2, \mathrm{C} 2-\mathrm{C} 3$, and $\mathrm{C} 3-\mathrm{C} 31$ bonds of $1.9866(18), 1.350-$ (2), and of $1.473(2) \AA$ are typical of a $\mathrm{Ru}-\mathrm{C}\left(\mathrm{sp}^{2}\right)$ single bond, a $\mathrm{C}=\mathrm{C}$ double bond and a $\mathrm{C}\left(\mathrm{sp}^{2}\right)-\mathrm{C}\left(\mathrm{sp}^{2}\right)$ single bond, respectively. Similar bond lengths for $\mathrm{Ru}-\mathrm{C} 2$ (1.984(5)) and C2C3 (1.346(9)) are found for 1c and related five-coordinated vinyl complexes. ${ }^{33,39-42}$ Structural features of the vinylpyrenyl part of 3c show essentially the same bond-length pattern as that observed in styryl ${ }^{43}$ or alkynyl substituted pyrenes. ${ }^{44,45}$ The chloroform solvate molecule forms an almost linear $\mathrm{CH} \cdots \mathrm{Cl}-$ $\mathrm{Ru}$ array with a $\mathrm{H} \cdots \mathrm{Cl}$ distance of $2.56 \AA$, a $\mathrm{C} \cdot \cdots \mathrm{Cl}$ distance of $3.551 \AA$, and a $\mathrm{CH} \cdots \mathrm{Cl}$ angle of $169^{\circ}$.

All attempts to crystallize the $\mathrm{PPh}_{3}$ substituted counterpart 3a only led to the formation of few small crystals of a distinctly lighter, yellow color as that of the bulk sample. These were subjected to X-ray analysis and turned out as the $\mathrm{PPh}_{3}$ adduct 3a-P. The structure of 3a-P, as depicted in Figure 2 (only one of two independent molecules is shown), bears clear witness to the distortion of the coordination sphere around ruthenium induced by the strong trans influence of the vinyl ligand and the steric hindrance of three meridionally displaced $\mathrm{PPh}_{3}$ ligands. Thus, the distances between the ruthenium atom and the mutually trans disposed P atoms P1, P2 (molecule A) or P4, P5 (molecule B) of 2.4221(13) and 2.4024(13) $\AA$ or 2.4397(13) and 2.4446(13) $\AA$ are distinctly smaller than those of 2.5850(13) or 2.5638(14) $\AA$ involving the $\mathrm{PPh}_{3}$ ligand trans to the pyrenylvinyl group. Steric congestion at the metal center is also evident from the strongly compressed $\mathrm{P} 1-\mathrm{Ru}-\mathrm{P} 2$ (P4$\mathrm{Ru}-\mathrm{P} 5)$ angle of $161.74(4)^{\circ}(163.83(5))^{\circ}$ and from the bending of the phosphines toward the pyrenylvinyl ligand as opposed to the five-coordinated complexes $\mathbf{1 c}$ and $\mathbf{3 c}$. This distortion surpasses that observed in similar vinyl complexes bearing $\mathrm{PEt}_{3}$ or $\mathrm{PMe}_{3}$ coligands ${ }^{46-49}$ and also that observed in the closely

(43) Natarajan, A.; Mague, J. T.; Venkatesan, K.; Arai, T.; Ramamurthy, V. J. Org. Chem. 2006, 71, 1055-1059.

(44) Ziessel, R.; Goze, C.; Ulrich, G.; Césario, M.; Retailleau, P.; Harriman, A.; Rostron, J. P. Chem. Eur. J. 2005, 11, 7366-7378.

(45) Pohl, R.; Anzenbacher, Jr., P. Org. Lett. 2003, 5, 2769-2772.

(46) Xia, H. P.; Yeung, R. C. Y.; Jia, G. Organometallics 1998, 17, 47624768.

(47) Xia, H.; Wen, T. B.; Hu, Q. Y.; Wang, X.; Chen, X.; Shek, L. Y.; Williams, I. D.; Wong, K. S.; Wong, G. K. L.; Jia, G. Organometallics 2005, 24 562-569.

(48) Liu, S. H.; Chen, Y.; Wan, K. L.; Wen, T. B.; Zhou, Z.; Lo, M. F.; Williams, I. D.; Jia, G. Organometallics 2002, 21, 4984-4992.

(49) Yuan, P.; Liu, S. H.; Xiong, W.; Yin, J.; Yu, G.-a.; Sung, H. Y.; Williams, I. D.; Jia, G. Organometallics 2005, 24, 1452-1457.

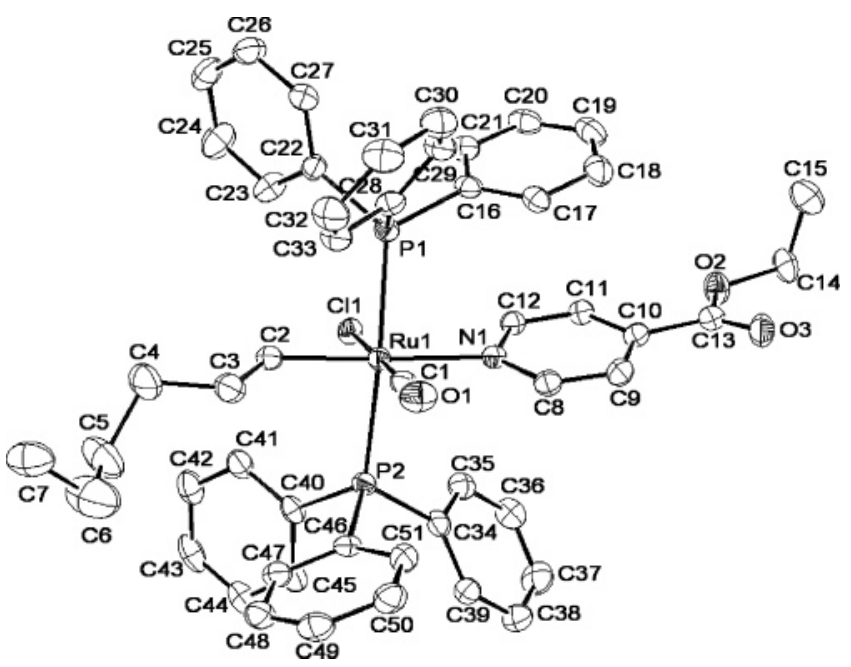

Figure 3. ORTEP representation of complex $\mathbf{1 b}$ at a $50 \%$ probability level.

related osmium complex $\left(\mathrm{PPh}_{3}\right)_{3}(\mathrm{CO}) \mathrm{ClOs}(\mathrm{CH}=\mathrm{CHPh})^{47}$ but resembles that in the recently reported divinyl phenylene bridged diruthenium complex $\left\{\left(\mathrm{PPh}_{3}\right)_{3}(\mathrm{CO}) \mathrm{ClRu}\right\}_{2}\left(\mu-\mathrm{CH}=\mathrm{CH}-\mathrm{C}_{6} \mathrm{H}_{4}-\right.$ $\mathrm{CH}=\mathrm{CH}-1,4){ }^{32}$ The long $\mathrm{Ru} 1-\mathrm{P} 3(\mathrm{Ru} 2-\mathrm{P} 6)$ bond also provides a good rationale for the facile loss and selective replacement of the phosphine ligand trans to the vinyl group.

The pyrenylvinyl ligand is nearly coplanar with the $\mathrm{Cl1}-$ $\mathrm{Ru}-\mathrm{C} 1$ axis and forms a torsional angle of $178.15(4)^{\circ}(\mathrm{Cl1}-$ $\mathrm{Ru} 1-\mathrm{C} 2-\mathrm{C} 3)$ or $-165.95(5)^{\circ}(\mathrm{Cl101}-\mathrm{Ru} 2-\mathrm{C} 102-\mathrm{C} 103)$. Again, the organic $\pi$-system and the ruthenium atoms are in direct conjugation as it is inferred from the torsional angles $\mathrm{Ru} 1-\mathrm{C} 2-\mathrm{C} 3-\mathrm{C} 4\left(-178.7(4)^{\circ}\right)$ and $\mathrm{Ru} 2-\mathrm{C} 102-\mathrm{C} 103-\mathrm{C} 104$ $\left(175.6(3)^{\circ}\right)$. In contrast to $\mathbf{3 c}$ the pyrenyl entities display some twist around the central $\mathrm{C}-\mathrm{C}$ bonds. Thus, the vinyl-substituted and the opposing, outermost six-membered rings of the condensed $\pi$ perimeter form angles of $5.9(2)^{\circ}$ or $3.9(3)^{\circ}$.

Complex 1b, the other crystallographically characterized sixcoordinated derivative of this study, features a much less distorted coordination environment. A view of the molecular structure of this complex is provided as Figure 3. Angles between trans ligands span a range of $176.46(3)^{\circ}$ to $179.46(8)^{\circ}$ while cis angles range from $86.40(6)^{\circ}$ to $93.45(1)^{\circ}$. The acute angle $\mathrm{N} 1-\mathrm{Ru}-\mathrm{Cl} 1$ of $86.40(6)^{\circ}$ is enforced by a hydrogen bond between an isonicotinate ortho $\mathrm{CH}$ proton and the adjacent

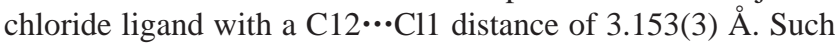
an interaction may contribute to the rotational barrier of the two isomers of $\mathrm{HRu}(\mathrm{CO}) \mathrm{Cl}\left(\mathrm{PPh}_{3}\right)_{2}$ (isonicotinate) (vide supra). Further C $\cdots \mathrm{Cl}$ contacts of 3.301(3) and 3.347(4) $\AA$ are observed to one ortho $\mathrm{CH}$ of a phenyl ring on each $\mathrm{PPh}_{3}$ ligand. While longer, these contacts are still well below the sum of the Van der Waals radii $(3.45 \AA) .{ }^{50}$ The substituted pyridine ligand is rotated by about $21^{\circ}$ out of the plane of the equatorial donors but resides in the same plane as the vinylic double bond.

The structure of the dodecenynyl complex $\mathrm{Ru}(\mathrm{CO}) \mathrm{Cl}\left(\mathrm{PPh}_{3}\right)_{2^{-}}$ $\left(\eta^{1}: \eta^{2}{ }^{n} \mathrm{BuHC}=\mathrm{CHC} \equiv \mathrm{C}^{n} \mathrm{Bu}\right)$ in its crystalline state is shown as Figure $\mathrm{S} 3$ of the Supporting Information. $\sigma, \pi$-Coordination of the enynyl ligand leads to a rather long $\mathrm{Ru}-\mathrm{C}$ (vinyl) $\sigma$-bond of 2.081(4) $\AA$ as compared to those in vinyl complexes like 1c, 3c, and 3a-P of ca. $1.98 \AA$. The $\mathrm{Ru}-\mathrm{C}$ bonds of 2.300(3) and 2.558(4) $\AA$ observed for the $\eta^{2}$-coordinated alkyne part of that

(50) Lide, D. R.; Frederikse, H. P. CRC Handbook of Chemistry and Physics, 76 ed.; CRC Press: Boca Raton, FL, 1995. 


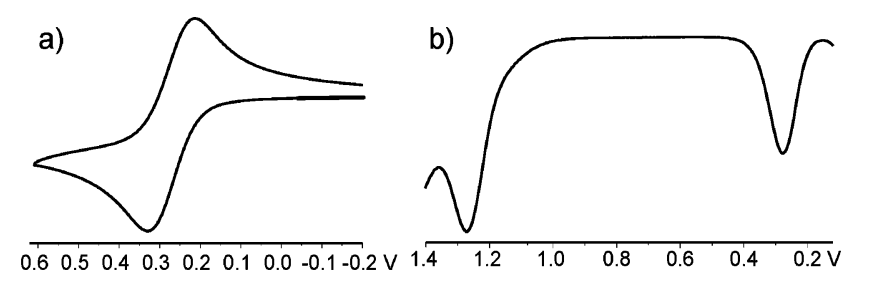

c)

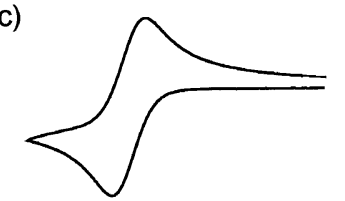

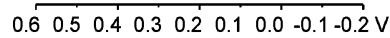

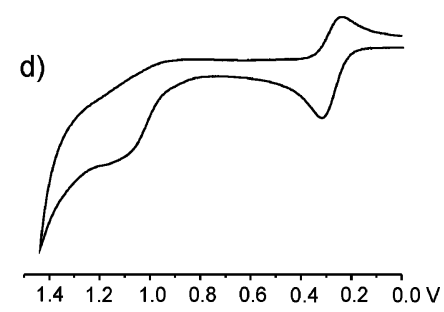

e)

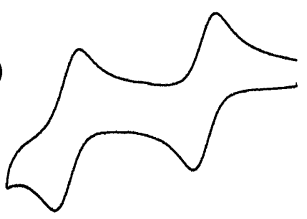

$\begin{array}{lllllll}1.0 & 0.8 & 0.6 & 0.4 & 0.2 & 0.0 & -0.2 \mathrm{~V}\end{array}$

Figure 4. Cyclic voltammograms of (a) complex 1c, (c and d) complex 2c and (e) complex 3c in $\mathrm{CH}_{2} \mathrm{Cl}_{2} / \mathrm{NBu}_{4} \mathrm{PF}_{6}(0.2 \mathrm{M})$ at $v=0.1 \mathrm{~V} / \mathrm{s}$. (b) Square wave voltammogram of complex $1 \mathrm{c}$ at $10 \mathrm{mV} / \mathrm{s}$. Potentials are given relative to the ferrocene/ferrocenium standard.

ligand are unusually long for this type of complexes, ${ }^{51}$ which points to steric crowding at the metal atom. The occupation of two cis positioned coordination sites by the enynyl ligand induces significant angular distortions in the equatorial plane. These are most evident by the acute angle $\mathrm{C} 6-\mathrm{Ru}-\mathrm{C} 8$ of 66.38 $(14)^{\circ}$ spanned by the outermost carbon atoms of the enynyl ligand and the ruthenium atom and the concomitant opening of the angles $\mathrm{C} 1-\mathrm{Ru}-\mathrm{Cl}$ and $\mathrm{C} 1-\mathrm{Ru}-\mathrm{C} 8\left(105.68(10)^{\circ}\right.$ and 102.58$(15)^{\circ}$, respectively). These and other structural features such as the bond lengths within the enynyl part of the organic ligand

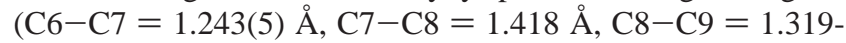
(5) $\AA$ ) closely resemble those of other ruthenium enynyl complexes. ${ }^{51}$

Electrochemistry. The vinyl complexes were studied by cyclic voltammetry in $\mathrm{CH}_{2} \mathrm{Cl}_{2} / \mathrm{NBu}_{4} \mathrm{PF}_{6}(0.2 \mathrm{M})$ as the supporting electrolyte. Representative voltammograms of complexes 1c, 2c, and 3c are shown in Figure 4; pertinent data are compiled in Table 1. A more complete set of voltammograms recorded for the studied vinyl complexes at room temperature and in a dry ice/isopropanol slush bath are provided as Figures S7-S15 of the Supporting Information. The $\mathrm{P}^{i} \mathrm{Pr}_{3}$-substituted five coordinated complexes $\mathbf{1 c}, \mathbf{2 c}$, and $\mathbf{3 c}$ undergo a reversible oneelectron oxidation at moderately positive potential. The radical cations of the five coordinated $\mathrm{PPh}_{3}$ substituted complexes $\mathbf{1 a}$, $\mathbf{2} \mathbf{a}$, and $\mathbf{3 a}$ are less stable as follows from $i_{\mathrm{p}, \mathrm{c}} / i_{\mathrm{p}, \mathrm{a}}$ peak current ratios of $0.37,0.63$, or 0.68 at $v=0.1 \mathrm{~V} / \mathrm{s}$ at room temperature. A second one-electron oxidation occurs at substantially higher potential. This process is completely irreversible at slow sweep rates and at room temperature. For $\mathbf{2 b}, \mathbf{c}$ the chemical follow processes underlying degradation of the mono- and dications are slowed down at faster sweep rates or upon cooling the cell in a dry ice/i PrOH slush bath such that $i_{\mathrm{p}, \mathrm{c}} / i_{\mathrm{p}, \mathrm{a}}$ ratios of unity

(51) Yang, S.-M.; Chan, M. C.-W.; Cheung, K.-K.; Che, C.-M.; Peng, S.-M. Organometallics 1997, 16, 2819-2826.
Table 1. Electrochemical Data of the Vinyl Complexes ${ }^{a}$

\begin{tabular}{lll}
\hline & $E_{1 / 2}{ }^{0+}$ in V & $E_{1 / 2^{+/ 2+}}$ in V \\
\hline $\mathbf{1 a}$ & $0.470^{c}$ & n.a. \\
$\mathbf{1 b}$ & $0.440^{d}$ & $1.42^{b}$ \\
$\mathbf{1 c}$ & 0.270 & $1.35^{b}$ \\
$\mathbf{2 a}$ & 0.330 & $0.795^{b}$ \\
$\mathbf{2 b}$ & 0.360 & $1.05^{b}$ \\
$\mathbf{2 c}$ & 0.280 & $0.850^{b}$ \\
$\mathbf{3 a}$ & $0.195^{c}$ & $0.54^{b}$ \\
& $0.19^{d}$ & $0.495^{c, d}$ \\
3b & $0.180^{c}$ & $0.620^{c}$ \\
& $0.220^{d}$ & $0.670^{d}$ \\
3c & 0.155 & 0.660 \\
\hline
\end{tabular}

${ }^{a}$ Data in $\mathrm{CH}_{2} \mathrm{Cl}_{2} / 0.2 \mathrm{M} \mathrm{NBu}_{4} \mathrm{PF}_{6}$ at room temperature unless stated otherwise. Potentials are calibrated against the internal $\mathrm{Cp}_{2} \mathrm{Fe}^{0 /+}$ couple which is set as $0.00 \mathrm{~V} .{ }^{b}$ Peak potential of an irreversible process at $v=$ $0.1 \mathrm{~V} / \mathrm{s} .{ }^{c}$ Half-wave potential of a partially reversible wave. ${ }^{d}$ At $195 \mathrm{~K}$.

for the first oxidation were achieved and half-wave potentials of the second oxidation process could be determined. For the 1-pyrenylvinyl complexes $\mathbf{3 a}-\mathbf{c}$ the two consecutive oneelectron oxidations are more closely spaced than for the hexenyl and styryl complexes with $\Delta E_{1 / 2}=E_{1 / 2}{ }^{+/ 2+}-E_{1 / 2}{ }^{0 /+}$ values of 350 to $500 \mathrm{mV}$. The lowering of especially the second oxidation potential renders the radical cation of $\mathbf{3} \mathbf{a}$ and even the dication of $3 \mathbf{c}$ stable, at least on the voltammetric time scale of about $10 \mathrm{~s}$.

A comparison of the data in Table 1 reveals the following trends: (i) Extending the vinyl ligand's $\pi$-system from hexenyl to styryl and to 1-pyrenylvinyl shifts the oxidation potentials of both processes to more cathodic values. (ii) The effect of extending the vinyl ligand's $\pi$-system is much larger for the second oxidation. (iii) Within each series of compounds $1 \mathbf{1 a}-\mathbf{c}$, $\mathbf{2} \mathbf{a}-\mathbf{c}$, and $\mathbf{3 a}-\mathbf{c}$ the first oxidation potentials follow the order five-coordinate ${ }^{i} \operatorname{Pr}_{3}(\mathbf{1 c}, \mathbf{2 c}, \mathbf{3 c})<$ five-coordinate $\mathrm{PPh}_{3}(\mathbf{1 a}$, $\mathbf{2 a}, \mathbf{3 a}) \approx$ six-coordinate isonicotinate adducts $(\mathbf{1 b}, \mathbf{2 b}, \mathbf{3 b})$. This matches the trends for the $\mathrm{CO}$ band shifts and the electron densities at the metal center. Similar observations have been reported for divinylphenylene-bridged diruthenium complexes $\left\{\left(\mathrm{PR}_{3}\right)_{2}(\mathrm{CO}) \mathrm{Cl}\left(\mathrm{L}^{\prime}\right) \mathrm{Ru}\right\}_{2}\left\{\mu-\mathrm{C}_{6} \mathrm{H}_{4}-(\mathrm{CH}=\mathrm{CH})_{2}-1,3\right.$ or $\left.-1,4\right)(\mathrm{R}=$ $\mathrm{Ph}, \mathrm{L}^{\prime}=4$-substituted pyridine; $\mathrm{R}={ }^{i} \mathrm{Pr}, \mathrm{L}^{\prime}=$ none) ${ }^{27,28} \mathrm{On}$ the other hand, the observed cathodic shift of $40-50 \mathrm{mV}$ between related complexes of series $\mathbf{a}$ and $\mathbf{c}$ is notably smaller than expected on the basis of Levers $E_{\mathrm{L}}$ parameters for $\mathrm{PPh}_{3}$ $(0.39 \mathrm{~V})$ and trialkylphosphines (e.g., $\left.\mathrm{P}^{n} \mathrm{Pr}_{3}=0.29\right) .{ }^{52}$ In Lever's approach, the anodic oxidation potential of the metal centered $\mathrm{Ru}^{\mathrm{II} / \mathrm{III}}$ couple is expressed by eq 1 , where $\Sigma E_{\mathrm{L}}$ denotes the sum of the $E_{\mathrm{L}}$ parameters of each ligand. Substituting two $\mathrm{PPh}_{3}$ by two $\mathrm{P}^{i} \mathrm{Pr}_{3}$ ligands should thus decrease the oxidation potential by about $200 \mathrm{mV} .^{53}$

$$
E\left(\mathrm{Ru}^{\mathrm{II} / I I I}\right)=0.97 \sum E_{\mathrm{L}}+0.04 \mathrm{~V}
$$

There are two possible explanations for these trends: On one hand, the vinyl ligand becomes more electron rich as $\pi$-conjugation increases, thus decreasing its $E_{\mathrm{L}}$ parameter. This renders oxidation more facile. Support for this idea comes from a

(52) Lever, A. B. P. Inorg. Chem. 1990, 29, 1271-1285.

(53) Similar parameter sets have been proposed by Leigh, Pickett, and Pombeiro. These are linearly related to the more extensive ones of Lever. See for example: (a) Chatt, J.; Kan, C. T.; Leigh, G. L.; Pickett, C. J.; Stanley, D. L. J. Chem. Soc., Dalton Trans.1980, 2032-2038. (b) Zhang, L.; Guedes da Silva, M. F. C.; Kuznetsov, M. L.; Gamasa, M. P.; Gimeno, J.; Frausto da Silva, J. J. R.; Pombeiro, A. J. L. Organometallics, 2001, 20, 27822793. 
comparison of the calculated HOMO energies of 1-hexene $(-9.97 \mathrm{eV}),{ }^{54}$ propene $(-9.73 \mathrm{eV}),{ }^{55}$ styrene $(-7.87 \mathrm{eV}),{ }^{55}$ and of the 1-propylpyrenyl localized HOMO $(-7.64 \mathrm{eV})$ of a pyrenyl donor/perylene-3,4,9,10-bis(dicarboximide) dyad. ${ }^{56}$ In this view the oxidation would still be a metal-centered process. Alternatively, extending the vinyl ligand's $\pi$-system increases its contribution to the occupied FMOs that govern the oxidation processes (orbital mixing). The lower energy of the oxidized forms then mainly relies on more extensive delocalization of the positive charge(s) across the organic $\pi$-system. We will show that this is indeed the case and that replacing the hexenyl by the styryl and pyrenylvinyl ligands alters the character of the first oxidation from a metal/ligand delocalized to a ligand dominated process. The even stronger effect of vinyl ligand substitution on the second oxidation potential suggests that the alteration of relative metal/ligand contributions is even more pronounced for the second oxidation process. We also note that the first oxidation potentials of the vinyl complexes are much lower than those of comparable alkenes, styrenes, and pyrenes (cf. $E_{1 / 2}=1.11 \mathrm{~V}$ for $\alpha$-methylstyrene and $1.20 \mathrm{~V}$ for styrene, ${ }^{54}$ $E_{1 / 2}=$ ca. $0.9 \mathrm{~V}$ for pyrene ${ }^{57}$ and 2-ethynylpyrene derivatives ${ }^{44}$ ), but also than those of related ruthenium complexes such as $\mathrm{RuCl}_{2}(\mathrm{CO})\left(\mathrm{PPh}_{3}\right)_{2}$ (py-R) $\left(\mathrm{R}=\right.$ substituted pyridine, $E_{1 / 2}=$ $0.66-0.76 \mathrm{~V}),{ }^{58}$ or $\mathrm{HRu}(\mathrm{CO}) \mathrm{Cl}\left(\mathrm{P}^{i} \mathrm{Pr}_{3}\right)_{2}\left(E_{\mathrm{p}}=0.505 \mathrm{~V}\right)$ and $\mathrm{RuCl}_{2}(\mathrm{CO})\left(\mathrm{P}^{i} \mathrm{Pr}_{3}\right)_{2}\left(E_{1 / 2}=0.625 \mathrm{~V}\right)$ as determined by us. Cathodic shifts of ca. $400 \mathrm{mV}$ for the pyrene-based oxidation have been observed in pyrenyl phenylene vinylene conjugates. ${ }^{59}$ The low oxidation potentials observed for the vinyl complexes thus provide further evidence for an efficient conjugation within the organometallic chromophore.

IR-Spectroelectrochemistry. Owing to the synergistic nature of the metal carbonyl bond the oxidation induced shift of $\tilde{v}(\mathrm{CO})$ provides an ideal tool for gauging the metal contribution to the oxidation process. A metal-centered one-electron oxidation is expected to increase the energy of the CO stretch by $100-150$ $\mathrm{cm}^{-1}$ as less electron density is transferred from the metal atom to the $\pi^{*}$ orbitals of the carbonyl ligand. Representative examples in ruthenium chemistry are provided by $\mathrm{Ru}\left(\mathrm{PR}_{3}\right)_{2}(\mathrm{CO})_{3}{ }^{0 /+}$ pairs of complexes, where blue-shifts of $120-130 \mathrm{~cm}^{-1}$ upon oxidation have been reported. ${ }^{60}$

With this in mind, complexes $\mathbf{1 b}-\mathbf{c}, \mathbf{2} \mathbf{a}-\mathbf{c}$ and $\mathbf{3 a}-\mathbf{c}$ were oxidized inside an optically transparent thin layer electrolysis (OTTLE) cell ${ }^{61}$ under IR monitoring. Results of this study are displayed as Figures 5-7 and as Figures S16-S22 of the Supporting Information. Table 2 summarizes the $\tilde{v}(\mathrm{CO}), \tilde{v}(\mathrm{C}=$ $\mathrm{C})$, and, if applicable, the $\tilde{v}$ (COOEt) data for the complexes in their various oxidation states.

The chemical reversibility of the second oxidations of 1-pyrenylvinyl complexes $\mathbf{3 b}, \mathbf{c}$ even allowed us to generate and

(54) Engels, R.; Schäfer, H. J.; Steckhan, E. Liebigs Ann. Chem. 1977, 204224.

(55) Zhan, G.-G.; Nichols, J. A.; Dixon, D. A. J. Phys. Chem. A 2003, 107, 4184-4195.

(56) Shumate, W. J.; Mattern, D. L.; Jaiswal, A.; Dixon, D. A.; White, T. R.; Burgess, J.; Honciuc, A.; Metzger, R. M. J. Phys. Chem. B 2006, 110 $11146-11159$.

(57) Daub, J.; Engl, R.; Kurzawa, J.; Miller, S. E.; Schneider, S.; Stockmann, A.; Wasiliewski, M. R. J. Phys. Chem. A 2001, 105, 5655-5665.

(58) Wohnrath, K.; Batista, A. A.; Ferreira, A. G.; Zukerman-Schpector, J.; de Oliveira, L. A. A.; Castellano, A. E. Polyhedron 1998, 17, 2013-2020.

(59) Mizutani, M. Adv. Colloid Interface Sci. 1997, 71-72, 111-124.

(60) Sherlock, S. J.; Boyd, D. C.; Moasser, B.; Gladfelter, W. L. Inorg. Chem. 1991, 20, 3626-3632

(61) Krejcik, M.; Danek, M.; Hartl, F. J. Electroanal. Chem. 1991, 317, 179187.

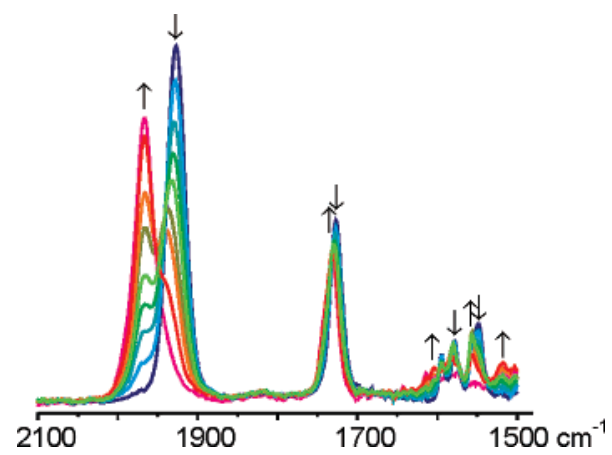

Figure 5. IR spectroelectrochemistry: spectroscopic changes during oxidation of complex $\mathbf{2 b}\left(\mathrm{NBu}_{4} \mathrm{PF}_{6} / \mathrm{DCE}\right)$.

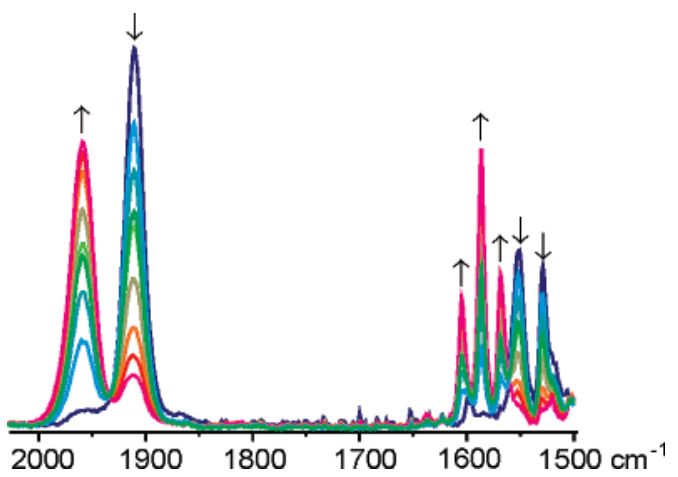

Figure 6. IR spectroelectrochemistry: spectroscopic changes during the first oxidation of complex $\mathbf{3 c}\left(\mathrm{NBu}_{4} \mathrm{PF}_{6} / \mathrm{DCE}\right)$.

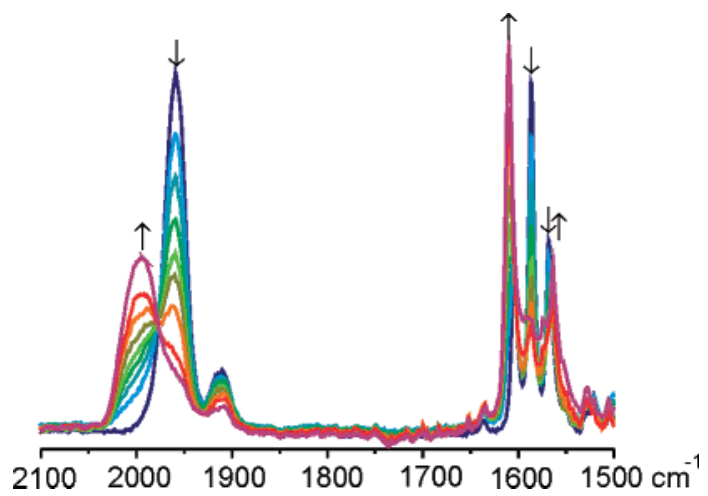

Figure 7. IR spectroelectrochemistry: spectroscopic changes during the second oxidation of complex $3 \mathbf{c}\left(\mathrm{NBu}_{4} \mathrm{PF}_{6} / \mathrm{DCE}\right)$.

to spectroscopically characterize their corresponding dications by IR spectroelectrochemistry. The second oxidation induces a further, yet even smaller blue shift of the CO band than was observed for the first oxidation. Pertinent data are provided in Table 2 (see also Figures 7 and S22 of the Supporting Information).

Comparison of the data in Table 2 reveals the following: (i) For each series $\mathbf{a}-\mathbf{c}$ the overall $\mathrm{CO}$ band shift upon oxidation consistently decreases with increasing $\pi$ conjugation of the substituent at the vinyl ligand. (ii) Oxidation induced $\mathrm{CO}$ band shifts are larger for the five-coordinate complexes and are seemingly independent of the nature of the phosphine ligands. The distinctly lower CO band shifts in the $18 \mathrm{VE}$ isonicotinate adducts show that the weak $\pi$ acceptor pyridine coligands serve as electron buffers to ruthenium as is indicated by the concomitant blue-shift of the isonicotinate ester band. (iii) Even for the hexenyl complexes $\mathbf{1 b}, \mathbf{c}$ the $\mathrm{CO}$ band shifts are considerably smaller than is expected of a metal centered 
Table 2. IR Data for Complexes $\mathbf{1 a}-\mathbf{c}, \mathbf{2} \mathbf{a}-\mathbf{c}$, and $\mathbf{3 a}-\mathbf{c}$ in Their Various Oxidation States

\begin{tabular}{|c|c|c|c|}
\hline & $\tilde{v}(\mathrm{CO})$ & $\Delta \tilde{v}(\mathrm{CO})$ & $\tilde{v}(\mathrm{C}=\mathrm{C})$ \\
\hline $1 \mathbf{a}$ & 1931 & & 1587(w) \\
\hline $1 \mathrm{~b}$ & 1923 & & $1726^{b}$ \\
\hline $1 b^{+}$ & 1968 & 45 & $1731^{b}$ \\
\hline 1c & 1906 & & $1586(\mathrm{~m})$ \\
\hline $1 \mathbf{c}^{+}$ & 1983 & 77 & $1580(\mathrm{~m})$ \\
\hline $2 \mathbf{a}$ & 1912 & & $1595(\mathrm{w}), 1585(\mathrm{~m}), 1562(\mathrm{~m}), 1553(\mathrm{~m})$ \\
\hline $2 \mathbf{b}$ & 1927 & & $1726(\mathrm{~s}), b 1594(\mathrm{w}), 1578(\mathrm{~m}), 1548(\mathrm{~m})$ \\
\hline $2 \mathbf{b}^{+}$ & 1967 & 40 & $1730(\mathrm{~s}),{ }^{b} 1613(\mathrm{w}), 1580(\mathrm{~m}), 1556(\mathrm{~m}), 1519(\mathrm{w})$ \\
\hline $2 c$ & 1911 & & $1595(\mathrm{w}), 1579(\mathrm{~m}), 1554(\mathrm{~m})$ \\
\hline $2 c^{+}$ & 1976 & 65 & $1595(\mathrm{w}), 1579(\mathrm{~m}), 1576(\mathrm{~m}), 1554(\mathrm{~m})$ \\
\hline 3a & 1935 & & 1600(w), 1584(w), 1556(m), 1531(m) \\
\hline $3 \mathbf{a}^{+}$ & 1983 & 48 & $1600(\mathrm{sh}), 1588(\mathrm{~m})$ \\
\hline $3 \mathbf{b}$ & 1927 & & $1727,,^{b} 1599(\mathrm{w}), 1550(\mathrm{~m}), 1527(\mathrm{~m})$ \\
\hline $3 \mathbf{b}^{+}$ & 1962 & 35 & $1730^{b} 1601(\mathrm{~m}), 1587(\mathrm{~m})$ \\
\hline $3 \mathbf{b}^{2+}$ & 1984 & 22 & $17411^{b} 1612(\mathrm{~m}), 1559(\mathrm{~m}), 1521(\mathrm{w})$ \\
\hline 3c & 1911 & & 1599(w), 1552(s), 1529(s) \\
\hline $3 c^{+}$ & 1959 & 48 & $1605(\mathrm{~s}), 1586(\mathrm{~s}), 1569(\mathrm{~s})$ \\
\hline $3 \mathbf{c}^{2+}$ & 1993 & 34 & $1610(\mathrm{~s}), 1574(\mathrm{w}), 1564(\mathrm{~m}), 1529(\mathrm{w})$ \\
\hline
\end{tabular}

${ }^{a}$ Energies are given for $1,2-\mathrm{C}_{2} \mathrm{H}_{4} \mathrm{Cl}_{2}$ solutions in $\mathrm{cm}^{-1}$. ${ }^{b}$ Isonicotinate ester band.

Table 3. Electronic Spectra of the Vinyl Complexes in Their Various Oxidation States

\begin{tabular}{|c|c|}
\hline & $\lambda_{\text {max }}\left(\epsilon_{\max }\left[\mathrm{M}^{-1} \mathrm{~cm}^{-1}\right]\right)$ \\
\hline 1b & $400(2200)$ \\
\hline 1c & $290(\mathrm{sh}, 3700), 328(1120), 383(1600), 512(320)$ \\
\hline $1 c^{+}$ & $296(8600), 340(\mathrm{sh}), 508(1800), 980(200)$ \\
\hline 2a & $310(14300), 376(2750), 490(820)$ \\
\hline 2b & $308(23000), 406(3700), 522(300)$ \\
\hline $\mathbf{2 b}^{+}$ & $397(3600), 686(6500), 967(595), 1020(545)$ \\
\hline $2 c$ & $272(\mathrm{sh}, 1750), 306(3200), 381(580), 510(290)$ \\
\hline $2 c^{+}$ & 272(1800), 301(2270), 388(2640), 633(1145), 875(280) \\
\hline 3a & $296(\mathrm{sh}, 13700), 386(12200), 486(1600), 584(1200)$ \\
\hline $3 \mathbf{a}^{+}$ & $\begin{array}{l}350(\text { sh, 8400), 363(9000), 385(9200), 465(3800), } \\
\quad 603(2300), 1150(1700)\end{array}$ \\
\hline $3 \mathbf{b}$ & $\begin{array}{l}\text { 265(sh, 39000), 285(sh, 25000), 300(23000), } \\
\quad 414(29000), 603(420)\end{array}$ \\
\hline $3 \mathbf{b}^{+}$ & $278(37000), 348(18000), 608(10000), 1139(4100)$ \\
\hline $3 c$ & $264(\mathrm{sh}, 15700), 309(11000), 414(17000), 510(1200)$ \\
\hline $3 c^{+}$ & $\begin{array}{l}277(13000), 346(8800), 376(8900), 395(8400) \\
\quad 415(7700), 509(3900), 551(8100) \\
\text { 594(11900), 704(1100), 1086(5650) }\end{array}$ \\
\hline
\end{tabular}

oxidation. Taking the redox pairs $\mathrm{Ru}\left(\mathrm{PR}_{3}\right)_{2}(\mathrm{CO})_{3}{ }^{0 /+}$ as benchmark systems and assuming a CO band shift of $130 \mathrm{~cm}^{-1}$ for a ruthenium centered process, the metal contribution to oxidation of the $\mathrm{P}^{i} \mathrm{Pr}_{3}$ complexes can be estimated as ca. $60 \%$ (1c), 50\% (2c), and as ca. $35 \%$ (3c) of that in the benchmark systems. For complexes $\mathbf{3 b}, \mathbf{c}$, the second oxidation is even more centered on the 1-pyrenylvinyl ligand than the first one. IR-spectroelectrochemistry thus provides clear evidence for "non-innocent" behavior of even simple alkyl substituted vinyl ligands in these ruthenium complexes.

Vis-NIR Spectroelectrochemistry. Electronic spectra of the parent hexenyl and styryl complexes in the visible region are dominated by an only moderately intense absorption band of mainly vinyl ligand to metal charge transfer (LMCT) for the five-coordinated complexes of series a and $\mathbf{c}$ or mixed vinyl to pyridine ligand/metal-to-pyridine ligand (LLCT/MLCT) character for complexes of series $\mathbf{b}$. For complexes $3 \mathbf{a}-\mathbf{c}$ the pyrenyl-based absorption appears as an intense band near 410 $\mathrm{nm}$ without resolved vibrational structure (see Table 3 and Figure 8). We note a substantial red shift of this band with

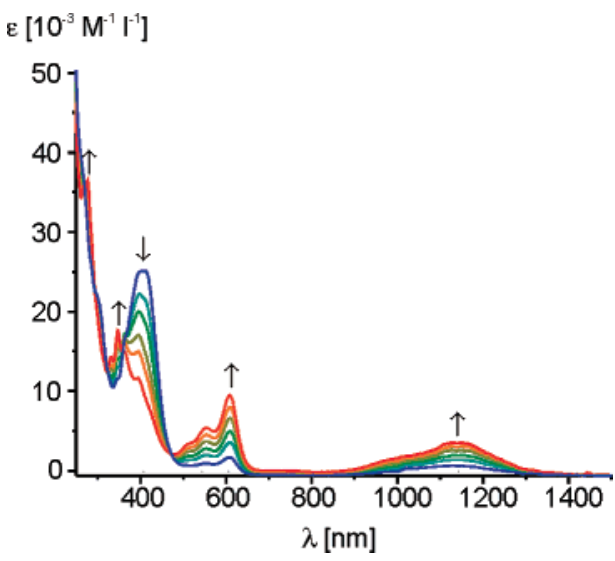

Figure 8. UV-vis-NIR spectroelectrochemistry: spectroscopic changes upon the first oxidation of complex $\mathbf{3} \mathbf{b}\left(\mathrm{NBu}_{4} \mathrm{PF}_{6} / \mathrm{DCE}\right)$.

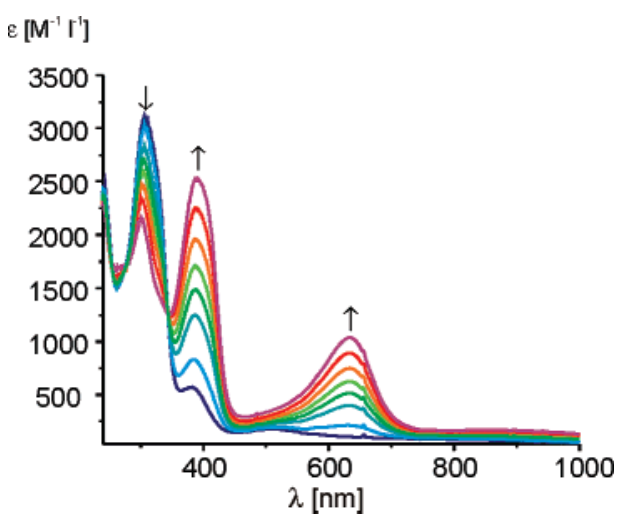

Figure 9. UV-vis-NIR spectroelectrochemistry: spectroscopic changes upon the first oxidation of complex $2 \mathbf{c}\left(\mathrm{NBu}_{4} \mathrm{PF}_{6} / \mathrm{DCE}\right)$.

respect to pyrene, ${ }^{62} 1$-phenylpyrene derivatives,${ }^{57}$ and 1-ethynylpyrene, ${ }^{62}$ whose optical absorptions peak at $330-350 \mathrm{~nm}$. This, and the loss of the characteristic vibrational fine structure of the pyrene chromophore signal efficient electronic conjugation between the pyrenyl and the vinylruthenium entities. ${ }^{57,63}$ The five-coordinated derivatives 1a,c, 2a,c and 3a,c also display a weak absorption $\left(\epsilon<1000 \mathrm{M}^{-1} \mathrm{~cm}^{-1}\right)$ in the $500-600 \mathrm{~nm}$ range that are typical of $\mathrm{d}-\mathrm{d}$ type transitions of $\mathrm{d}^{6} \mathrm{ML}_{5}$ complexes of ruthenium. ${ }^{64-66}$

Oxidation of the vinyl complexes in an OTTLE cell under UV-vis-NIR monitoring induces the collapse of the LMCT or LLCT/MLCT bands and the simultaneous growth of intense absorptions at lower energies in the visible and the near-infrared (NIR, see Figures 8, 9 and Figures S23-S25 of the Supporting Information). With clearly discernible vibrational splittings of $1500-1570 \mathrm{~cm}^{-1}$ the overall appearance of the individual bands is highly reminiscent of that of alkene and arene radical cations, including that of styrene and various pyrene derivatives. ${ }^{67-69}$

(62) Marsh, N. D.; Mikolajczak, C. J.; Wornat, M. J. Spectrochim. Acta 2000 , A 56, 1499-1511.

(63) Harriman, A.; Hissler, M.; Ziessel, R. Phys. Chem. Chem. Phys. 1999, 1, 4203-4211.

(64) Briggs, J. C.; McAuliffe, C. A.; Dyer, G. J. Chem. Soc., Dalton Trans 1984, 423-427.

(65) Mezzetti, A.; Del Zotto, A.; Rigo, P.; Pahor, R. B. J. Chem. Soc., Dalton Trans. 1989, 1045-1052.

(66) Winter, R. F.; Hornung, F. M. Inorg. Chem. 1997, 36, 6197-6204.

(67) Shida, T. Electronic Absorption Spectra of Radical Ions; Elsevier: Amsterdam, The Netherlands, 1988.

(68) Tsuchida, A.; Ikawa, T.; Yamamoto, M.; Ishida, A.; Takamuku, S. J. Phys. Chem. 1995, 99, 14793-14797.

(69) Shafirovich, V. Y.; Levin, P. P.; Kuzmin, V. A.; Thorgeirsson, T. E.; Kliger, D. S.; Geacintov, N. S. J. Am. Chem. Soc. 1994, 116, 63-72. 


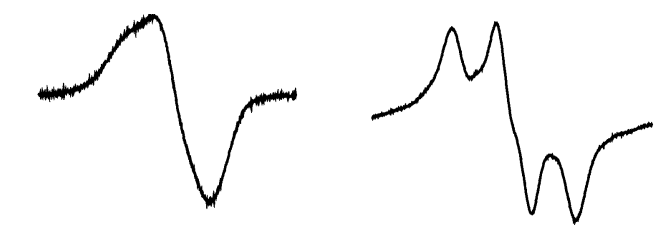

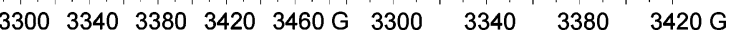

Figure 10. X-band ESR spectra of the radical cation of complex $2 \mathrm{c}\left(\mathrm{NBu}_{4}\right.$ $\left.\mathrm{PF}_{6} / \mathrm{DCE}\right)$ at $110 \mathrm{~K}$ (left) and at room temperature (right).

Table 4. Experimental and Calculated ESR Data of Oxidized Mononuclear Ru-Vinyl Complexes ${ }^{a}$

\begin{tabular}{lllllcl}
\hline & \multicolumn{1}{c}{$g_{\mathrm{iso}}{ }^{b}$} & \multicolumn{1}{c}{$g_{\mathrm{av}}{ }^{c}$} & \multicolumn{1}{c}{$g_{1}$} & \multicolumn{1}{c}{$g_{2}$} & $g_{3}$ & \multicolumn{1}{c}{$\Delta g$} \\
\hline $\mathbf{1 c}^{+}$ & & 2.023 & 2.050 & 2.018 & 2.001 & 0.049 \\
$\mathbf{2 b}^{+}$ & 2.010 & 2.0473 & 2.0653 & 2.0382 & & 0.0271 \\
$\mathbf{2 c}^{+}$ & $2.0448^{d}$ & & & & & \\
$\mathbf{3 b}^{+}$ & 2.0243 & 2.0242 & 2.039 & 2.0225 & 2.011 & 0.0280 \\
$\mathbf{3 c}^{+}$ & $2.0032^{e}$ & 2.0132 & 2.0263 & 2.0066 & & 0.0197 \\
$\mathbf{1 c}^{\mathrm{Me}+}$ & & 2.0248 & 2.0958 & 2.0553 & 2.0452 & 0.0506 \\
$\mathbf{1 c}^{+}$ & & 2.0186 & 2.0894 & 2.0513 & 2.0460 & 0.0434 \\
$\mathbf{2 b}^{\mathrm{Me}+}$ & & 2.0116 & 2.0829 & 2.0560 & 2.0503 & 0.0326 \\
$\mathbf{2 c ^ { M e + }}$ & & 2.0221 & 2.0606 & 2.0382 & 2.0320 & 0.0286 \\
$\mathbf{3 c}^{\mathrm{Me}+}$ & & 2.0159 & 2.0389 & 2.0271 & 2.0266 & 0.0123 \\
\hline
\end{tabular}

${ }^{a}$ Radical cations were electrogenerated $\left(\mathrm{CH}_{2} \mathrm{Cl}_{2} / \mathrm{NBu}_{4} \mathrm{PF}_{6}\right)$ inside an ESR tube. ${ }^{b}$ Isotropic $g$-value in fluid solution. ${ }^{c}$ Average $g$-value at $77 \mathrm{~K} .{ }^{d} A\left({ }^{31} \mathrm{P}\right)$ $=21.5 \mathrm{G} .{ }^{e} A\left({ }^{31} \mathrm{P}\right)=17.2 \mathrm{G}$

There is again a notable red-shift of the bands in the oxidized vinyl complexes when compared to the oxidized forms of their purely organic counterparts. As an example, the absorption bands of the parent styryl radical cation at 344 and $614 \mathrm{~nm}^{67}$ are shifted to 388 and $633 \mathrm{~nm}$ in $\mathbf{2 c}^{+}$. Photoionized trans-1styrylpyrene absorbs at $580 \mathrm{~nm} .^{70}$ The corresponding radical cation band of $\mathbf{3 b}, \mathbf{c}^{+}$is observed at 608 and $594 \mathrm{~nm}$, respectively. The results of UV-vis-NIR spectroelectrochemistry thus confirm the dominant organic character of the vinyl complex radical cations and extensive electron delocalization within the metalloorganic chromophore.

ESR Spectroscopy. Metal-centered paramagnetic species display fundamentally different properties in their ESR spectra than organic-based radicals. This is particularly true for $\mathrm{Ru}-$ (III) complexes, which are mostly ESR silent at room-temperature owing to rapid relaxation processes. ${ }^{60}$ Spectra recorded at low temperatures, usually in frozen matrices, display axial or rhombic $g$-tensors with large $g$-anisotropies, that is, large differences between the individual components of the $g$-tensor, and average $g$-values distinctly different than the free electron value $g_{\mathrm{e}}$ of $2.0023 .^{71-73}$ Organic radicals, on the other hand, typically display richly structured isotropic signals at room temperature, $g$-values close to that of the free electron, and $g$-value anisotropies which are too small to be resolved in the $\mathrm{X}$-band. ESR spectroscopy is thus ideally suited to probe the character of the vinyl complex radical cations.

Oxidized samples of most vinyl complexes were electrogenerated inside an ESR tube. With the exception of $\mathbf{1} \mathbf{c}^{+}$and $\mathbf{2} \mathbf{b}^{+}$, which became ESR active only upon cooling, all other

(70) Ellsei, F.; Aloisi, G. G.; Latterini, L.; Galiazzo, G.; Görner, H. J. Chem Soc.: Faraday Trans. 1995, 91, 3117-3121.

(71) Sakaki, S.; Hagiwara, N.; Ohyoshi, A. J. Phys. Chem. 1978, 82, 19171920.

(72) Raynor, J. B.; Jeliazkowa, B. G. J. Chem. Soc., Dalton Trans. 1982, $1185-$ 1189.

(73) Dinelli, L. R.; Batista, A. A.; Wohnrath, K.; de Araujo, M. P.; Queiroz, S. L.; Bonfadini, M. R.; Olivia, G.; Nascimento, O. R.; Cyr, P. W.; MacFarlane, K. S.; James, B. R. Inorg. Chem. 1999, 38, 5341-5345.

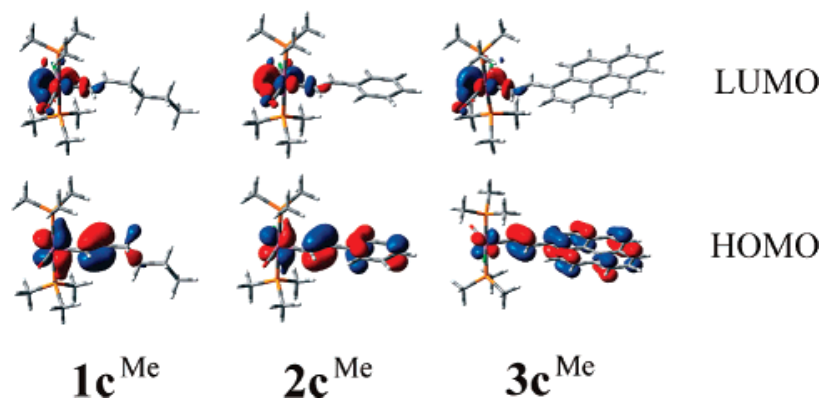

Figure 11. Contour plots of the frontier orbitals of complexes $1 c^{\mathrm{Me}}, \mathbf{2 c ^ { \mathrm { Me } }}$, and $3 \mathrm{c}^{\mathrm{Me}}$

Chart 2. Vinyl Model Complexes Employed in This Study and Their Designation

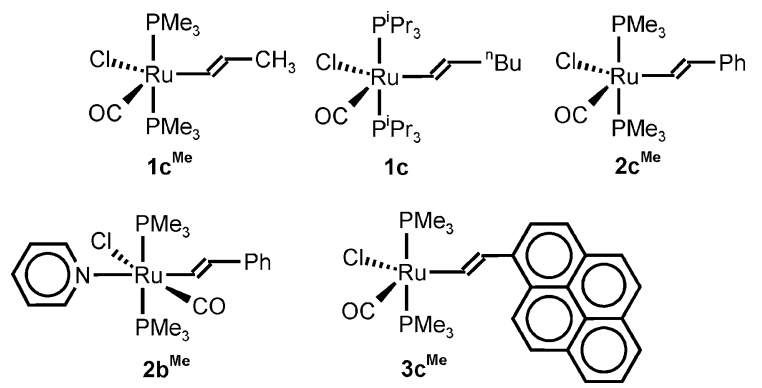

investigated radical cations display intense isotropic spectra in fluid solution at room temperature (see Figure 10 and Figures S26 to S29 of the Supporting Information and Table 4). This bears clear witness to their dominant organic character. Some metal contribution to the SOMO is evidenced by the line broadening, which in most cases conceals hyperfine splittings to the vinyl protons and the P-atoms of the phosphine ligands. Excemptions are the radical cations $\mathbf{2 c}^{+}$and $\mathbf{3} \mathbf{c}^{+}$where resolved hyperfine couplings to the ${ }^{31} \mathrm{P}$ nuclei of 21.5 and $17.2 \mathrm{G}$, respectively, were observed in fluid solution. Further manifestations of metal contribution to the SOMO orbital are the deviation of the measured $g$-values from $g_{\mathrm{e}}$ and some discernible axial or rhombic splitting of the $g$-tensor in frozen matrices $(110 \mathrm{~K})$. The $g$-value anisotropies are, however, much smaller than those usually associated with $\mathrm{Ru}(\mathrm{III})$ species. ${ }^{74}$

Smaller $g$-tensor anisotropies $\Delta g$ and smaller deviations of the average $g$-value from $g_{\mathrm{e}}$ are observed as the covalency of the Ru-ligand bond increases and more spin density is shifted to the ligand. Recent examples of $\mathrm{Ru}(\mathrm{III})$ alkynyl complexes document close correlations between (calculated) metal contributions to the SOMO and the $\Delta g$ parameter. ${ }^{75,76}$ In none of these cases, however, $g$-value anisotropies as small as those in mono- and dinuclear ${ }^{27,28}$ vinyl complexes have been observed.

Quantum Chemistry. Quantum chemical calculations on models of the mononuclear ruthenium vinyl complexes were carried out in order to (i) assess metal versus ligand contributions to the frontier molecular orbitals (fmos) that are involved in the redox chemistry and in the low-energy optical transitions, (ii) investigate how extending $\pi$-conjugation within the vinyl ligand affects the fmo composition, (iii) rationalize the electronic spectra of the complexes, (iv) establish how oxidation changes

(74) Patra, S.; Sarkar, B.; Mobin, S. M.; Kaim, W.; Lahiri, G. K. Inorg. Chem. 2003, 42, 6469-6473.

(75) Paul, F.; Ellis, B. G.; Bruce, M. I.; Toupet, L.; Roisnel, T.; Costuas, K.; Halet, J.-F.; Lapinte, C. Organometallics 2006, 25, 649-665.

(76) Klein, A.; Lavastre, O.; Fiedler, J. Organometallics 2006, 25, 635-643. 
Table 5. Calculated FMO Compositions of Mononuclear Ru-Vinyl Model Complexes.

\begin{tabular}{|c|c|c|c|c|c|c|c|c|c|}
\hline model & MO & $E(\mathrm{eV})$ & prevailing character & $\mathrm{Ru}$ & vinyl & $\mathrm{R}$ & $\mathrm{CO}$ & $\mathrm{Cl}$ & PR3 \\
\hline \multirow[t]{4}{*}{$1 \mathrm{c}^{\mathrm{Me}}$} & LUMO+1 & -0.21 & $\mathrm{~d}_{\mathrm{Ru}}$ & 60 & 1 & 0 & 6 & 3 & 30 \\
\hline & LUMO & -1.62 & $\mathrm{~d}_{\mathrm{Ru}}$ & 60 & 13 & 1 & 11 & 3 & 11 \\
\hline & HOMO & -5.30 & $\mathrm{~d}_{\mathrm{Ru}}+\pi_{\mathrm{vinyl}}$ & 46 & 43 & 4 & 0 & 1 & 2 \\
\hline & HOMO-1 & -6.15 & $\mathrm{~d}_{\mathrm{Ru}}$ & 61 & 4 & 0 & 17 & 16 & 2 \\
\hline \multirow[t]{4}{*}{$1 c$} & LUMO+1 & -0.16 & $\mathrm{~d}_{\mathrm{Ru}}$ & 56 & 0 & 0 & 7 & 5 & 32 \\
\hline & LUMO & -1.39 & $\mathrm{~d}_{\mathrm{Ru}}+\mathrm{PR}_{3}$ & 59 & 13 & 1 & 9 & 3 & 15 \\
\hline & HOMO & -5.38 & $\mathrm{~d}_{\mathrm{Ru}}+\pi_{\mathrm{vinyl}}$ & 40 & 41 & 5 & 0 & 0 & 13 \\
\hline & HOMO-1 & -6.33 & $\mathrm{~d}_{\mathrm{Ru}}+\mathrm{Cl}$ & 63 & 4 & 0 & 17 & 14 & 1 \\
\hline \multirow[t]{4}{*}{$2 c^{M e}$} & LUMO+1 & -0.44 & $\pi_{\text {vinyl }}+\pi_{\mathrm{Ph}}$ & 8 & 32 & 58 & 0 & 0 & 1 \\
\hline & LUMO & -1.55 & $\mathrm{~d}_{\mathrm{Ru}}$ & 60 & 13 & 1 & 11 & 3 & 11 \\
\hline & HOMO & -5.38 & $\mathrm{~d}_{\mathrm{Ru}}+\pi_{\mathrm{vinyl}}+\pi_{\mathrm{Ph}}$ & 28 & 37 & 30 & 0 & 0 & 4 \\
\hline & HOMO - 1 & -6.55 & $\mathrm{~d}_{\mathrm{Ru}}$ & 60 & 5 & 0 & 17 & 17 & 1 \\
\hline \multirow[t]{6}{*}{$2 b^{\mathrm{Me}}$} & $\mathrm{LUMO}+3$ & -0.17 & $\mathrm{~d}_{\mathrm{Ru}}$ & 58 & 2 & 0 & 18 & 5 & 14 \\
\hline & LUMO + 2 & -0.20 & $\pi_{\text {vinyl }}^{*}+\pi^{*}{ }_{\mathrm{Ph}}$ & 8 & 28 & 61 & 0 & 0 & 1 \\
\hline & LUMO + 1 & -0.40 & $\pi_{\mathrm{py}}^{*}$ & 3 & 0 & 0 & 0 & 0 & 1 \\
\hline & LUMO & -0.98 & $\pi_{\text {py }}^{*}$ & 4 & 0 & 0 & 0 & 0 & 0 \\
\hline & HOMO & -5.15 & $\mathrm{~d}_{\mathrm{Ru}}+\pi_{\mathrm{vinyl}}+\pi_{\mathrm{Ph}}$ & 29 & 39 & 29 & 0 & 0 & 2 \\
\hline & HOMO - 1 & -6.25 & $\mathrm{~d}_{\mathrm{Ru}}$ & 50 & 4 & 0 & 32 & 12 & 0 \\
\hline \multirow[t]{4}{*}{$3 c^{\mathrm{Me}}$} & LUMO + 1 & -1.54 & $\pi_{\mathrm{pyr}}+\pi_{\mathrm{vinyl}}$ & 3 & 10 & 87 & 0 & 0 & 0 \\
\hline & LUMO & -1.59 & $\mathrm{~d}_{\mathrm{Ru}}$ & 60 & 12 & 1 & 12 & 3 & 12 \\
\hline & HOMO & -5.08 & $\pi_{\mathrm{pyr}}+\pi_{\mathrm{vinyl}}+\mathrm{d}_{\mathrm{Ru}}$ & 14 & 21 & 63 & 0 & 0 & 2 \\
\hline & HOMO - 1 & -6.14 & $\pi_{\mathrm{pyr}}+\pi_{\mathrm{vinyl}}+\mathrm{d}_{\mathrm{Ru}}$ & 21 & 13 & 63 & 0 & 1 & 2 \\
\hline
\end{tabular}

Table 6. TDDFT (G03/PBE0/CPM $\left.\left(\mathrm{CH}_{2} \mathrm{Cl}_{2}\right)\right)$ Singlet Excitation Energies (eV) for $\mathbf{1 c}, \mathbf{2} \mathbf{b}^{\mathbf{M e}}, \mathbf{2} \mathbf{c} \mathbf{\mathrm { Me }}\left(\mathrm{G} 03 / \mathrm{PBE} / \mathrm{CPCM}\left(\mathrm{CH}_{2} \mathrm{Cl}_{2}\right)\right)$, and $\mathbf{3} \mathbf{c}^{\mathrm{Me}}$ (G03/PBE1PBE/CPCM $\left(\mathrm{CH}_{2} \mathrm{Cl}_{2}\right)$ ) with Oscillator Strengths Larger than 0.001

\begin{tabular}{|c|c|c|c|c|c|c|}
\hline model & state & main components (\%) & $\begin{array}{c}\text { transition energy } \\
{[\mathrm{eV}(\mathrm{nm})]}\end{array}$ & osc str & $\begin{array}{l}\text { expt trans } \\
{[\mathrm{nm}]}\end{array}$ & $\begin{array}{c}\text { ext coeff } \\
{\left[\mathrm{M}^{-1} \mathrm{~cm}^{-1}\right]}\end{array}$ \\
\hline \multirow[t]{5}{*}{$1 c$} & $\mathrm{a}^{1} \mathrm{~A}$ & $91(\mathrm{HOMO} \rightarrow$ LUMO) & $2.28(544)$ & 0.05 & 512 & 320 \\
\hline & $\mathrm{b}^{1} \mathrm{~A}$ & 88 (HOMO-2 $\rightarrow$ LUMO) & $3.18(390)$ & 0.027 & 383 & 1600 \\
\hline & $\mathrm{f}^{1} \mathrm{~A}$ & $82(\mathrm{HOMO} \rightarrow \mathrm{LUMO}+1)$ & $3.60(344)$ & 0.024 & 328 & 1120 \\
\hline & $\mathrm{h}^{1} \mathrm{~A}$ & 37 (HOMO-3 $\rightarrow$ LUMO) & $4.14(299)$ & 0.029 & 290 & 3700 \\
\hline & $\mathrm{i}^{1} \mathrm{~A}$ & $30(\mathrm{HOMO}-1 \rightarrow \mathrm{LUMO}+1)$ & $4.35(285)$ & 0.065 & & \\
\hline \multirow[t]{4}{*}{$2 \mathbf{b}^{\mathrm{Me} a}$} & $\mathrm{~b}^{1} \mathrm{~A}$ & $90(\mathrm{HOMO} \rightarrow$ LUMO $)$ & $2.34(529)$ & 0.005 & 521 & 300 \\
\hline & $c^{1} \mathrm{~A}$ & 98 (HOMO-1 $\rightarrow$ LUMO) & $3.16(392)$ & 0.025 & 394 & 3700 \\
\hline & $\mathrm{f}^{1} \mathrm{~A}$ & $70(\mathrm{HOMO}-3 \rightarrow$ LUMO $)$ & $4.05(306)$ & 0.025 & 308 & 23000 \\
\hline & $\mathrm{g}^{1} \mathrm{~A}$ & $98(\mathrm{HOMO} \rightarrow \mathrm{LUMO}+1)$ & $4.23(293)$ & 0.634 & & \\
\hline \multirow[t]{4}{*}{$2 \mathrm{c}^{\mathrm{Me}}$} & $\mathrm{b}^{1} \mathrm{~A}$ & 98 (HOMO $\rightarrow$ LUMO) & $3.50(354)$ & 0.133 & 383 & 580 \\
\hline & $\mathrm{e}^{1} \mathrm{~A}$ & $97(\mathrm{HOMO} \rightarrow \mathrm{LUMO}+1)$ & $4.08(304)$ & 0.017 & 306 & 3200 \\
\hline & $\mathrm{f}^{1} \mathrm{~A}$ & $78(\mathrm{HOMO}-1 \rightarrow \mathrm{LUMO}+3)$ & $4.19(296)$ & 0.181 & & \\
\hline & $\mathrm{g}^{1} \mathrm{~A}$ & $87(\mathrm{HOMO} \rightarrow \mathrm{LUMO}+2)$ & $4.26(291)$ & 0.464 & & \\
\hline \multirow[t]{7}{*}{$3 c^{\mathrm{Me}}$} & $\mathrm{a}^{1} \mathrm{~A}$ & $92(\mathrm{HOMO} \rightarrow$ LUMO) & $2.18(569)$ & 0.003 & 510 & 1200 \\
\hline & $\mathrm{b}^{1} \mathrm{~A}$ & $92(\mathrm{HOMO} \rightarrow \mathrm{LUMO}+1)\left(\pi \pi^{*}\right)$ & $2.98(416)$ & 0.938 & 414 & 17000 \\
\hline & $\mathrm{f}^{1} \mathrm{~A}$ & $80(\mathrm{HOMO} \rightarrow \mathrm{LUMO}+2)$ & $3.45(359)$ & 0.042 & n.d. & n.d. \\
\hline & $\mathrm{h}^{1} \mathrm{~A}$ & 37 (HOMO-1 $\rightarrow$ LUMO+1) & $3.92(316)$ & 0.077 & 309 & 11000 \\
\hline & & $40(\mathrm{HOMO} \rightarrow \mathrm{LUMO}+4)$ & & & & \\
\hline & $\mathrm{i}^{1} \mathrm{~A}$ & $30(\mathrm{HOMO}-1 \rightarrow \mathrm{LUMO}+1)$ & $4.01(309)$ & 0.124 & & \\
\hline & & $42(\mathrm{HOMO} \rightarrow \mathrm{LUMO}+4)$ & & & & \\
\hline
\end{tabular}

${ }^{a}$ Contributions missing to $100 \%$ correspond to py ligand-based orbitals.

the bonding within the organometallic Ru-vinyl chromophore, and (v) compare the experimentally observed $\mathrm{CO}$ and $\mathrm{C}=\mathrm{C}$ frequencies for the accessible oxidation states and the $g$ parameters of the radical cations to those predicted by theory. The phosphine ligands were modeled as $\mathrm{PMe}_{3}$ for most calculations. To probe for the effect of such simplification, the model complex $\mathrm{Cl}(\mathrm{CO})\left(\mathrm{PMe}_{3}\right)_{2} \mathrm{Ru}(\mathrm{CH}=\mathrm{CHMe})\left(\mathbf{1} \mathrm{c}^{\mathrm{Me}}\right)$ was compared to fully optimized 1c. The effect of six versus five coordination was finally addressed by comparing $\mathrm{Cl}(\mathrm{CO})$ $\left(\mathrm{PMe}_{3}\right)_{2} \mathrm{Ru}(\mathrm{CH}=\mathrm{CHPh})\left(\mathbf{2 c}^{\mathrm{Me}}\right)$ and $(\mathrm{py}) \mathrm{Cl}(\mathrm{CO})\left(\mathrm{PMe}_{3}\right)_{2} \mathrm{Ru}(\mathrm{CH}=$ $\mathbf{C H P h})\left(\mathbf{2} \mathbf{b}^{\mathbf{M e}}\right)$ as models of complexes $\mathbf{2 a}, \mathbf{c}$ and $\mathbf{2 b}$. The model complexes employed in the computational study and their designation are summarized in Chart 2.

The optimized structures of the model complexes agree well with the experimental ones (see Tables S11 to S14 of the Supporting Information). Deviations between experimental and calculated structures are restricted to the immediate vicinity of the vinyl bond.
Contour plots of crucial fmos of the complexes $1 \mathbf{c}^{\mathrm{Me}}, \mathbf{2} \mathbf{c}^{\mathrm{Me}}$, and $\mathbf{3} \mathbf{c}^{\mathrm{Me}}$ are provided as Figure 11, while Table 5 lists their compositions as obtained by Mulliken analysis. These data fully conform to our experimental observation that metal contribution to the occupied frontier levels decreases as the $\pi$-conjugation of the vinyl ligand increases. For the propenyl and hexenyl systems $\mathbf{1 c}^{\mathrm{Me}}$ and 1c the HOMO is fully delocalized over the Ru-vinyl entity. Vinyl ligand contributions to the HOMO become more and more important as the organic $\pi$-system extends. It increases from $47 \%$ in $1 \mathbf{c}^{\mathrm{Me}}$ or $46 \%$ in fully optimized 1c to $67 \%$ in $\mathbf{2} \mathbf{c}^{\mathrm{Me}}$ and $84 \%$ in $\mathbf{3} \mathbf{c}^{\mathrm{Me}}$. This clearly justifies denoting them as "non-innocent". A comparison of model complex $1 \mathbf{c}^{\mathrm{Me}}$ and the accurate model of 1c shows, that approximating $\mathrm{P}^{i} \mathrm{Pr}_{3}$ by $\mathrm{PMe}_{3}$ coligands underestimates the phosphine contribution to the HOMO and LUMO orbitals. The LUMO of all five coordinated complexes is essentially a ruthenium d-orbital with contributions from the phosphine and carbonyl ligands such that the electronic transition at the lowest 
Table 7. Calculated IR Parameters of Vinyl Complexes in Their Various Oxidation States.

\begin{tabular}{|c|c|c|c|c|}
\hline & & $n=0$ & $n=1$ & $n=2$ \\
\hline $1 \mathrm{c}^{\mathrm{Me} n+}$ & $\tilde{v}(\mathrm{CO})$ & 1926.9 & 1988.5 & 2045.0 \\
\hline $1 \mathbf{c}^{n+}$ & $\tilde{v}(\mathrm{CO})$ & 1924.5 & 1986.0 & 2037.5 \\
\hline \multirow[t]{2}{*}{$2 b^{M e} n+$} & $\tilde{v}(\mathrm{CO})$ & 1916.0 & 1961.0 & 2001.5 \\
\hline & $\tilde{v}(\mathrm{CC})$ & 1554.2 & 1597.0 & 1607.4 \\
\hline \multirow[t]{2}{*}{$2 \mathrm{c}^{\mathrm{Me} n+}$} & $\tilde{v}(\mathrm{CO})$ & 1927.6 & 1978.9 & 2024.9 \\
\hline & $\tilde{v}(\mathrm{CC})$ & 1549.9 & 1595.7 & 1607.9 \\
\hline \multirow[t]{3}{*}{$3 \mathrm{c}^{\mathrm{Me} n+}$} & $\tilde{v}(\mathrm{CO})$ & 1926.9 & 1967.2 & 2002.5 \\
\hline & $\tilde{v} 1(\mathrm{CC})$ & 1550.2 & 1606.7 & 1608.4 \\
\hline & $\tilde{v} 2(\mathrm{CC})$ & 1526.6 & 1584.0 & 1576.8 \\
\hline
\end{tabular}

energy is assigned as a mixed ligand-to-metal/ligand-to-ligand charge-transfer band (LMCT/LLCT). This is also borne out by TDDFT calculations which account for $\mathrm{CH}_{2} \mathrm{Cl}_{2}$ solvation. As is seen from the comparison in Table 6 , the calculated spectra reproduce the experimental ones well. On the basis of these calculations, the lowest energy band at ca. $510 \mathrm{~nm}$ is assigned as the HOMO-LUMO transition. Higher energy transitions within the styryl and pyrenyl complexes have dominant $\pi \rightarrow \pi^{*}$ character owing to sizable contributions of the vinyl ligand to the LUMO $+\mathrm{n}$ and the HOMO $-\mathrm{n}$ orbitals, particularly for the pyrenyl complex. For six-coordinated $\mathbf{2} \mathbf{b}^{\mathbf{M e}}$, however, two $\pi^{*}$ orbitals of the pyridine coligands are interspersed between the HOMO and the appropriate unoccupied metal d orbital such that the two lowest electron transitions assume mixed arylvinylto-pyridine (LLCT) and metal-to-pyridine charge transfer (MLCT) character.

To trace the effect of successive charge removal from the occupied frontier levels diagnostic IR parameters such as $\tilde{v}(\mathrm{CO})$ and $\tilde{v}(\mathrm{C}=\mathrm{C})$ of the model complexes were calculated for the neutral compounds and the oxidized mono- and dications. The compilation in Table 7 shows the expected decrease of oxidation-induced $\mathrm{CO}$ band shifts with decreasing HOMO metal character, paralleling our experimental results. Thus, for the first oxidation, $\Delta \tilde{v}(\mathrm{CO})$ diminishes from $61 \mathrm{~cm}^{-1}$ in the propenyl complex $\mathbf{1} \mathbf{c}^{\mathrm{Me}}$ to 51 in $\mathbf{2} \mathbf{c}^{\mathrm{Me}}$ and $40 \mathrm{~cm}^{-1}$ for $\mathbf{3} \mathbf{c}^{\mathrm{Me}}$. The calculations slightly underestimate $\Delta \tilde{v}(\mathrm{CO})$, which is mostly due to somewhat high $\tilde{v}(\mathrm{CO})$ values for the neutral complexes. For the styryl and pyrenylvinyl complexes the energies of the vinyl and substituent $\mathrm{C}=\mathrm{C}$ bands are predicted to increase with the overall oxidation state. We note again good agreement with the experimental data, particularly for the pyrenylvinyl complexes where these vibrations are rather intense. Computed ESR parameters as they are given in Table 4 fully reproduce the experimentally observed small $g$-anisotropies $\Delta g$, the systematic decrease of $\Delta g$ with increasing $\pi$-conjugation and lower metal character of the SOMO as well as the small deviations of the average $g$-values from $g_{\mathrm{e}}$.

Conclusions and Perspectives. Taken together, our experimental and computational results provide compelling evidence that even simple alkenyls behave as "non-innocent" ligands when coordinated to $\mathrm{Ru}(\mathrm{CO}) \mathrm{Cl}\left(\mathrm{PR}_{3}\right)_{2}(\mathrm{~L})(\mathrm{L}=$ electron donating or weakly $\pi$-accepting coligand) entities. Extending the conjugation within the vinyl ligand gradually alters the nature of the HOMO and, accordingly, of the anodic redox processes from fully delocalized across the metal-vinyl entity to ligand dominated with smaller, yet still discernible metal contributions. Such a situation is opposite to that encountered in most $\pi$-bridged dimetal complexes that are often invoked as models and principal constituents of organometallic "molecular wires". ${ }^{77-81}$ There, the occupied frontier levels are metal centered and the metal atoms interact through direct orbital overlap with the $\pi$-conjugated bridge. In our case, delocalization of the ligand centered HOMO onto the metal atoms suggests another possible way to construct extended electron conducting systems from vinyl ruthenium building blocks by employing the metal atoms as the conduit between two redox active ligands. Such a possibility has already been realized in a mononuclear bis(alkynyl) platinum complex. ${ }^{82}$ Our results add to a growing body of redox-active organometallic compounds where the organic $\pi$-ligand heavily participates in electron-transfer processes. ${ }^{79,80,83-85}$ Five-coordinated mononuclear ruthenium complexes as they were investigated herein offer an additional vacant coordination site trans to the vinyl ligand. This allows for the easy assembly of di- and oligonuclear systems with possibly high conductivity along the vinyl-metal-bridge chain by interconnecting them through appropriate bridging ligands or by employing alkynes with an additional coordinating functionality in the hydroruthenation reaction. This is the subject of ongoing research in our laboratories.

Acknowledgment. Financial support of this work by Deutsche Forschungsgemeinschaft (R.F.W., projects Wi 1262/7-1 and 436 TSE 113/45/0-1), by the Grant Agency of the Academy of Sciences of the Czech Republic (S.Z., Grant 1ET400400413), and the Ministry of Education of the Czech Republic (S.Z. Grant OC 139) are gratefully acknowledged.

Supporting Information Available: Synthetic procedures and characterization of compounds, Figures displaying the crystallographically determined structures of the complexes $\mathbf{1 b}, \mathbf{c}, \mathrm{Ru}-$ $(\mathrm{CO}) \mathrm{Cl}\left(\mathrm{PPh}_{3}\right)_{2}\left(\eta^{1}: \eta^{2}{ }^{n} \mathrm{BuHC}=\mathrm{CHC} \equiv \mathrm{C}{ }^{n} \mathrm{Bu}\right), \mathbf{3 a}-\mathbf{P} \cdot \mathbf{2} \mathbf{C H}_{\mathbf{2}} \mathbf{C l}_{\mathbf{2}}$ and $\mathbf{3 c} \cdot \mathbf{C H C l}_{\mathbf{3}}$ (Figures $\mathrm{S} 1-\mathrm{S} 5$ ); tables detailing the crystal data and structure refinement (Tables S1-S8); voltammograms of complexes $\mathbf{1 a}-\mathbf{c}, \mathbf{2} \mathbf{a}-\mathbf{c}$ and $\mathbf{3} \mathbf{a}-\mathbf{c}$ at room temperature and in an isopropanol/dry ice slush bath (Figures S6-S14); IR-spectroscopic changes upon the first oxidation of complexes $\mathbf{1 b}, \mathbf{1 c}$, $\mathbf{2 b}, \mathbf{3 a}$, and $\mathbf{3 b}(\mathrm{S} 15-\mathrm{S} 20)$, and upon the second oxidation of complex 3b (S21); Changes in the UV-vis-NIR spectrum of 1b (S22), 2b (S23), and 3b (S24); ESR spectra of the radical cations of complexes 1c, 3a,b, and 3b,c (S25-S28); tables of the G03/B3LYP and ADF/BP calculated bond parameters for the fully optimized complexes $\mathbf{1 c}$ and $\mathbf{3} \mathbf{c}^{\mathbf{M e}}$ (Tables S9, S10) and contour plots of all orbitals involved in the electronic transitions of Table 6 . This material is available free of charge via the Internet at http://pubs.acs.org.

JA075547T

(77) Weyland, T.; Costuas, K.; Toupet, L.; Halet, J.-F.; Lapinte, C. Organometallics 2000, 19, 4228-4239.

(78) Weyland, T.; Costuas, K.; Mari, A.; Halet, J.-F.; Lapinte, C. Organometallics 1998, 17, 5569-5579.

(79) Bruce, M. I.; Costuas, K.; Davin, T.; Ellis, B. G.; Halet, J.-F.; Lapinte, C.; Low, P. J.; Smith, M. E.; Skelton, B. W.; Toupet, L.; White, A. H. Organometallics 2005, 24, 3864-3881.

(80) Jiao, H.; Costuas, K.; Gladysz, J. A.; Halet, J.-F.; Guillemot, M.; Toupet, L.; Paul, F.; Lapinte, C. J. Am. Chem. Soc. 2003, 125, 9511-9522.

(81) Herrmann, C.; Neugebauer, J.; Gladysz, J. A.; Reiher, M. Inorg. Chem. 2005, 44, 6174-6182.

(82) Jones, S. C.; Coropceanu, V.; Barlow, S.; Kinnibrugh, T.; Timofeeva, T.; Brédas, J.-L.; Marder, S. R. J. Am Chem Soc. 2004, 126, 11782-11783.

(83) Wong, K. M.-C.; Lam, S. C.-F.; Ko, C.-C.; Zhu, N.; Yam, V. W.-W.; Roué S.; Lapinte, C.; Fathallah, S.; Costuas, K.; Kahlal, S.; Halet, J.-F. Inorg. Chem. 2003, 42, 7086-7097.

(84) de Montigny, F.; Argouarch, G.; Costuas, K.; Halet, J.-F.; Roisnel, T.; Toupet, L.; Lapinte, C. Organometallics 2005, 24, 4558-4572.

(85) Fox, M. A.; Roberts, R. L.; Khairul, W. M.; Hartl, F.; Low, P. J. J. Organomet. Chem. 2007, 692, 3277-3290. 